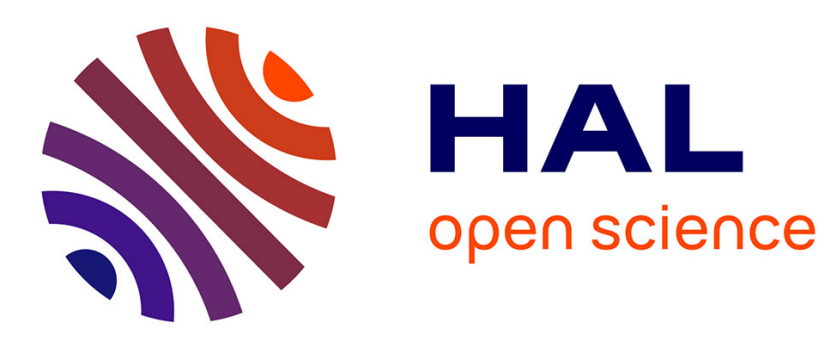

\title{
Sharing local ecological knowledge as a human adaptation strategy to arid environments: Evidence from an ethnobotany survey in Morocco
}

Julien Blanco, Stéphanie M Carrière

\section{- To cite this version:}

Julien Blanco, Stéphanie M Carrière. Sharing local ecological knowledge as a human adaptation strategy to arid environments: Evidence from an ethnobotany survey in Morocco. Journal of Arid Environments, 2016, Journal of Arid Environments, 127, pp.30 - 43. 10.1016/j.jaridenv.2015.10.021 . hal-01388049

\section{HAL Id: hal-01388049 \\ https://hal.science/hal-01388049}

Submitted on 4 Nov 2016

HAL is a multi-disciplinary open access archive for the deposit and dissemination of scientific research documents, whether they are published or not. The documents may come from teaching and research institutions in France or abroad, or from public or private research centers.
L'archive ouverte pluridisciplinaire HAL, est destinée au dépôt et à la diffusion de documents scientifiques de niveau recherche, publiés ou non, émanant des établissements d'enseignement et de recherche français ou étrangers, des laboratoires publics ou privés. 
Title: Sharing local ecological knowledge as a human adaptation strategy to arid environments: evidence from an ethnobotany survey in Morocco.

Authors: Julien BLANCO ${ }^{\mathrm{a}, 1}$, Stéphanie M. CARRIERE ${ }^{\mathrm{a}}$

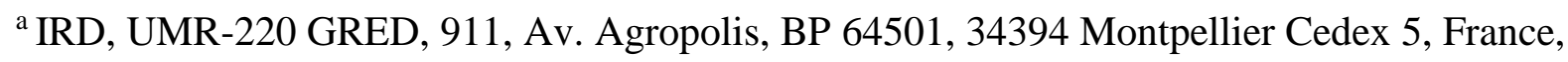
julien.blanco@ird.fr, stephanie.carriere@ird.fr

${ }^{1}$ Corresponding author: Phone: (33) 4676369 82; Fax: (33) 467638778

Abstract

In order to cope with uncertainty, human populations living in drylands have developed social-risk management strategies (SRMS) and own extended ecological knowledge (LEK), which contributes to their resilience and adaptive capacity. The aim of this study was to address LEK distribution and variability and to discuss LEK adaptation to drylands. Through ethnobotanical interviews and vegetation surveys in a Saharan Moroccan village, we tested the hypothesis that LEK is shaped by plant apparency and by SRMS. Out of 164 plants, 68 were useful for 126 distinct uses. Plant cultural value obtained from free-lists was positively correlated with plant use value. Plant apparency was positively correlated with plant cultural value, which corroborated the ecological apparency hypothesis. No effect of age or gender on LEK was observed. In contrast, permanentlysettled people had a lower level of knowledge than former nomads. The relative intracultural homogeneity of LEK suggests a reciprocal exchange network system strategy at the village scale, which may contribute to human adaptation and resilience to arid environments and to global changes. Nevertheless, LEK seemed interlocked with subsistence activities and with a mobile lifestyle. Conserving this lifestyle may thus be crucial for people's resilience in a context of an uncertain future.

Keywords

Local ecological knowledge, quantitative ethnobotany, cultural value, social risk-management strategy, plant use, Morocco. 


\section{Introduction}

Living and sustaining a livelihood in drylands (i.e dry subhumid, semiarid, arid, and hyper-arid terrestrial regions) is challenging for human populations. Drylands are highly stochastic environments characterised by harsh conditions, including scarce and unpredictable precipitation, high temperature, low soil fertility, sparse human settlements and remoteness (Reynolds et al., 2007). Under these conditions, human populations have developed adaptation strategies to manage risk and uncertainty, especially with regard to their pastoral activities. Among other examples, herd mobility is acknowledged as an adaptation to unpredictable resources (Niamir-Fuller, 1999) and herds' species diversification enables the optimal exploitation of the scarce vegetation (Coppock et al., 1986). These risk-management strategies imply both individual actions and cooperative local practices, embedded in global systems of social risk-management strategy (SRMS, Moritz et al., 2011). Such systems allow herders to collectively manage risk through specific social institutions, which contributes to collective and individual resilience. Three kinds of SRMS, aiming at enabling herds to recover after a crisis (such as severe droughts or diseases), are commonly distinguished. Firstly, in reciprocal exchange networks systems, pastoralists exchange, loan or give livestock, in order to reconstitute their herds. Secondly, in patron-client relationship systems, the reconstitution of herds involves the employment of impoverished herders as shepherds by wealthy ones. Finally, in some pastoral societies, SRMS are not institutionalised and support is circumscribed within a given group sphere (Moritz et al., 2011). The system of SRMS therefore regulates the circulation and the distribution of livestock between herders and contributes to the sustainability of the activity at society scale.

In complement to SRMS, herders have extended local ecological knowledge (LEK) of rangeland ecology. LEK, understood as "a cumulative body of knowledge, practice, and belief, evolving by adaptive processes and handed down through generations by cultural transmission, about the relationship of living beings (including humans) with one another and with their environment" (Berkes et al., 2000), contributes to people's resilience. The term 'resilience' is understood here as the capacity of human groups or individuals to cope with the disruption of their livelihoods and with a loss of security as a result of the impacts of social, economic or ecological changes (Adger, 2000). For drylands pastoralists, LEK notably enables a heavy sustained use of forage resources (Davis, 2005) and is furthermore associated with complementary subsistence activities and practices, such as tree tending (Andersen et al., 2014) or wild plant use (Ladio and Lozada, 2009). According to a broad range of factors, LEK is neither homogeneous nor static. Firstly, LEK depends on the plant material, as plants are not evenly used according to their characteristics (Phillips and Gentry, 1993a) or are not evenly available to people (de Lucena et al., 2012). 
Secondly, there is an intercultural variability of LEK, related to heterogeneity between cultural groups in terms of cultural preferences, activities, views of the world or socio-economic and environmental conditions (Berkes et al., 2000). Finally, there is an intracultural variability of LEK depending on age, gender, occupation, or on individual strategies and interests (Lawrence et al., 2005; Quinlan and Quinlan, 2007). Because LEK is not evenly distributed and is generally limited to small size groups, it increases the probability of losing knowledge through cultural oscillation (Begossi et al., 2002). Furthermore, LEK heterogeneity may constitute a sign of LEK erosion due to local societies' acculturation (e.g. Benz et al., 2000). Therefore, the intra- and intercultural heterogeneity in LEK systems contributes to their overall fragility and to people's vulnerability to changes, as LEK is linked with their socio-ecological resilience and adaptive capacity (Ruiz-Mallén and Corbera, 2013).

Considering the diverse strategies of societies in drylands to adapt their lifestyle and activities to environmental constraints (Niamir-Fuller, 1999), LEK systems may be somehow adapted to these constraints, which may influence LEK resilience in drylands. In this study, we propose to test this assumption by focusing on two aspects. On the one hand, the vegetation in drylands is characterized by general paucity and variability, and people have developed an opportunistic strategy in the exploitation of this resource (Salzman, 2002). In this context, we tested the hypothesis that the variability of use and knowledge on plants may be influenced by the availability of plants for human exploitation. This hypothesis is broadly known in the ethnobotanical research field as the Ecological Apparency Hypothesis (EAH), which assumes that people preferentially use and know plants that are more easily accessible (de Lucena et al., 2012). On the other hand, we tested the hypothesis that LEK systems are shaped by similar SRMS to those observed in pastoral activities. Transposing these strategies for LEK may lead to contrasted LEK distribution between people. The exchange networks strategy would imply that LEK is evenly shared among people via extensive circulation between social groups, genders, ages and so on. Under this assumption, LEK distribution between people may tend to be homogenous. On the other hand, the patron-client relationship strategy would imply a discrepancy between "wealthy" or knowledgeable people and the "poor" or less knowledgeable. This strategy may lead to a concentration of LEK within a specific group. Finally, the non-institutionalised SRMS strategy may lead to a gradient of knowledge between groups and heterogeneity according to socio-economic factors. Our main objectives were thus (1) to identify the useful plants and to assess their abundance in order to test the EAH, and (2) to quantify the intracultural variability of LEK in order to reveal what kind of SRMS are shaping LEK. We focused our investigations on a single village located in southwestern Morocco in the sub-Saharan area, in order to limit intercultural variation. This work 
provides a basis for discussion on the adaptation of LEK systems to drylands and their vulnerability in the face of changes in society.

\section{Materials and methods}

\subsection{STUDY SITE}

This study was a part of a broader $\mathrm{PhD}$ research study on the local management of the Saharan acacia woodlands and their conservation. Within the scope of this research, the first author spent a total of 170 days in two Saharan villages between January 2013 and August 2014. Apart from the ethnobotanical study presented in this paper, several observations made by the first author during his fieldwork were used here, especially in order to complete the study site presentation in a region where academic studies and literature are lacking, and to enrich the discussion of the results. This study was carried out in the village of Taidalt, in south-western Morocco, at the border between the Anti-Atlas Mountains and the Sahara desert (Figure 1). With mean annual rainfall of $112 \mathrm{~mm}$ and average temperature of $19.6^{\circ} \mathrm{C}$, the climate is arid with mild winters due the proximity of the Atlantic Ocean. Vegetation is characteristic of the Saharan biomes, with Acacia tortilis subsp. raddiana (Savi) Brenan (Leguminosae) as the dominant tree species and Hammada scoparia (Pomel) Iljin as the dominant shrub, locally associated with Panicum turgidum Forssk. in sandy riverbeds, Convolvulus trabutianus Schweinf. \& Muschler in terrace and Ziziphus lotus (L.) Lam in the plain (Msanda et al., 2002).

Taidalt village has about 398 inhabitants in 73 housing units (according to the Communal Development Plan) and is the traditional centre of the tribe Ouled Bouachra. The tribe is part of the tribal league Aït Noss, which also includes the tribes of Ait Zikri (village of El Borj - $15 \mathrm{~km}$ south of Taidalt), Aït Brahim (villages of Taghjicht and Targuameit - $50 \mathrm{~km}$ north-east of Taidalt) and Ä̈t Bou'ou (village of Tiglit - $60 \mathrm{~km}$ south-west of Taidalt).

Traditionally, people in this area were semi-nomadic herders living in tents. Villages and houses served as storage for families' grain and wealth and as meeting points for social events. Villages were built close to a spring and were also planted with date palm trees. The four tribes belonging to the tribal league Aït Noss share the same territory (Joumani, 2006). Most of this territory was an open-access rangeland for virtually all neighbouring Saharan tribes, according to "the "usufruct" principle of mutual non-destructive use of resources" (Andersen et al., 2014). In addition, the Ä̈t Noss cultivated grains (barley, maize and wheat) in areas occasionally flooded by unpredictable and stochastic rainfalls. Cultivation in this area did not necessarily occur every year, nor did it affect the same areas because of the high inter-annual variability of the rainfall: farmers decided whether to 
cultivate depending on the timing (a flood event must occur between September and March) and the extent of floods (Blanco et al., in press). The main area for grain cultivation was the plain adjacent to Taidalt, which was subdivided between the four tribes. In the same way, the village of Taghjicht constituted the main oasis, and every tribe owned some date palm trees there. This common management of the territory and its resources and the open-access principle of the rangeland are still in force today, so Taidalt inhabitants only constitute one of the user groups of the territory. In the middle of the 20th century, sedentarization started to occur in this region, resulting in the abandonment of pastoral activities by new settlers. During the fieldwork, people cited several reasons for this sedentarization, including schools, modern amenities (running water, electricity) and the loss of cattle after drought. Settled families in the village still continue to cultivate cereals during favourable years and own between five and 15 goats and/or sheep at home for domestic needs. Wage-earning jobs then became a complementary, or even the main, source of income for settled families.

In this context of on-going livelihood modernization, vegetation still constitutes a useful resource for the community. Firstly, vegetation still represents a forage resource for domestic small herds and for semi-nomadic herders. While in most houses and tents, cooking is done with gas, firewood and charcoal extracted for woody plants are still used for some specific preparations (e.g. bread and tea). Plants also ensure various everyday life needs, notably for traditional medicines, aromatic uses, goatskin tanning, fences around irrigated gardens and tent camps, etc. The use of plants is allowed both for members of Ait Noss and for herders from other tribes who browse their cattle on the territory. No extensive commercial exploitation of plants was observed during the fieldwork, even if surpluses may be sold, especially in the case of medicinal plants. As vegetation growth and abundance are highly variable in relation with rainfall, no clearly defined patterns of exploitation were identified during the year. Rather, plant exploitation was shaped by opportunistic behaviour, specific to nomad societies (Salzman, 2002). 


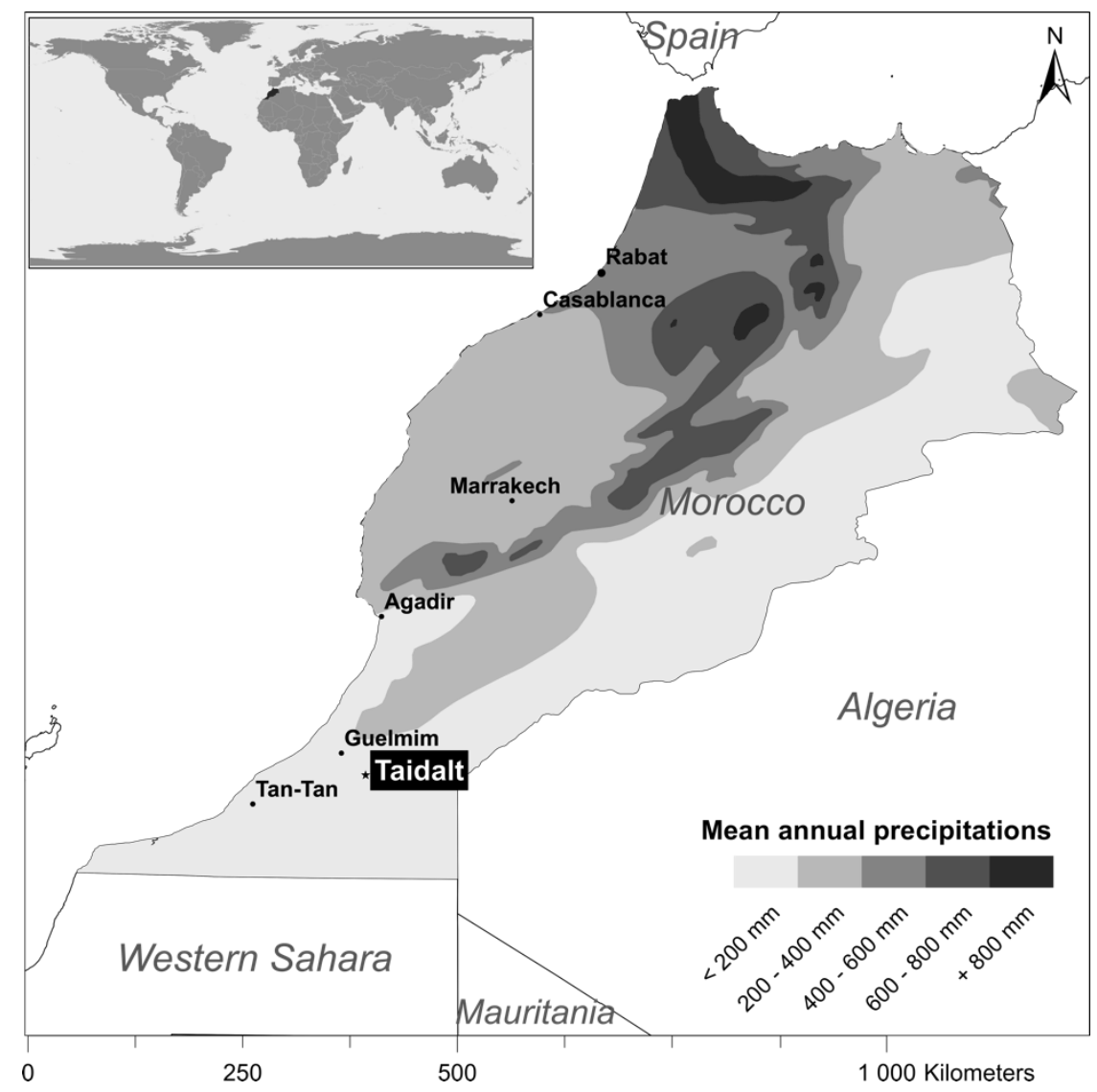

Figure 1: Study site location: Taidalt village, province of Guelmim, Morocco.

\subsection{DATA COLLECTION METHODOLOGY}

\subsubsection{Preliminary plant survey and investigations}

A preliminary phase consisted in the introduction of the first author into the village during a threeweek stay in June 2013. A local assistant was employed and trained to introduce the researcher and the purpose of the study to the villagers and to act as translator. The local language is Darija, the Moroccan dialect, mixed in this sub-Saharan area with Hassanya, the language spoken by Sahrawi people. The French speaking first author previously learned the basics of this language, which enabled spontaneous discussion with villagers. But for more formal exercises, such as structured and semi-structured interviews, the local assistant acted as interpreter. Pre-interviews were conducted to define an appropriate method to survey plant uses and knowledge. For instance, ethnobotanical transects or "walks-in-the-wood", common and effective methods in the tropics (e.g. Giday et al., 2009), were challenged here by the specificity of the area (including the absence of most plants during this period of drought, the scarcity of vegetation and the difficulty of finding volunteers to spend hours in the desert). Interviews in the village were finally found to better suit the local context. 
A survey of plant names through informal interviews with villagers was undertaken, and a total of two weeks were dedicated to botanical exploration of the village territory with three local informants and two shepherds. During this exploration, 82 specimens were collected for botanical identification and local names were obtained from informants. These names were then used in the semi-structured interview presented in section 2.2.2.

\subsubsection{Interviews}

Interviews were conducted in August 2013 with 37 informants who represented a range of socioeconomic attributes (Appendix A). We addressed the intracultural variability of LEK through age and gender - two parameters that usually shape LEK distribution (e.g. Benz et al., 2000; de Albuquerque et al., 2011). The selection of informants was thus based on these two criteria; our final sample was composed of 19 males and 18 females aged between 20 and 90 and were classified in four age classes in order to proceed to statistical analysis (Table 1). The size of the sample was challenged by several constraints. Firstly, the study occurred during a dry year, when a lot of sedentary people, in theabsence of agro-pastoral activities, went to urban centres to look for temporary jobs - such mobility is related with the opportunistic behaviour of people in arid environments and constitutes an adaptation strategy to drought (Salzman, 2002; Scoones, 1994). Secondly, some inhabitants refused to contribute to the study, for various reasons. It was for instance particularly difficult to have access to women, because the researcher and assistant were both men. An opportunistic sample frame was therefore chosen: informants were visited in their houses or encountered in the village and asked to participate to the study. After the informant consent, the interview occurred in the informant's home or in the village, away from crowded areas, and included two phases.

Firstly, an individual interview consisted in a free-listing exercise, during which the informant was asked to "cite, during a five-minute period, as many plants that grow on the tribe's territory as possible". A chronometer was started when the informant began to name plants and every plant name cited was noted in order of citation. Corresponding botanical names were obtained from the preliminary plant survey and identification, and from Bellakhdar (1997) and Volpato and Puri (2014), as drought and plant scarcity prevented the observation of all plants cited. This first phase resulted in 37 individual free-lists and enabled assessment of plant cultural value and its variability through ethnospecies and informants (see 2.3.1). The term ethnospecies refers to biological entities recognized by local informants, which do not necessarily correspond to taxonomic biological species (de Albuquerque et al., 2011). 
Secondly, a semi-structured interview was conducted, during which the interviewer proposed plant names randomly chosen from the list of names obtained in the preliminary phase. For each ethnospecies, the informant was asked about uses and processing. The number of plants proposed to each informant depended on the duration of the interview taking into account the informant's availability and willingness. Between four and 38 ethnospecies were investigated per interview for a total of 438 ethnospecies $\mathrm{X}$ interviews (Table 1). This data provided a basis for calculating plant use value and informants use knowledge (see section 2.3.2).

During interviews, questioning people in their own environment (home, village, etc.) appeared to be crucial in order to create an atmosphere of confidence and to maximize the information. In consequence, other people were present (family members, friends, etc.) during the interviews in 12 cases (out of 37). During the free-listing, secondary informants were asked remain silent. During the semi-structured interviews, they were invited to contribute after the interview with the main informant was completed. The information obtained by secondary informants enabled us to obtain an exhaustive list of uses and processing for each ethnospecies, and to calculate plant use value (see section 2.3.2). Finally, through the first and second phases of interviews, this study involved a total of 52 informants in 26 households (13\% of the total population of the village and $36 \%$ of the households). All analyses were performed on the basis of ethnospecies and not of botanical species.

Table 1: Number of informants and of ethnospecies proposed during the semi-structured interviews per gender and age.

\begin{tabular}{|c|c|c|c|c|c|}
\hline Age class (years) & 15-29 & $30-44$ & $45-59$ & $>59$ & Total \\
\hline \multicolumn{6}{|l|}{ Men } \\
\hline Sample size & 5 & 4 & 5 & 5 & 19 \\
\hline Number of species proposed & 61 & 30 & 78 & 98 & 267 \\
\hline Unknown species* & $31(51 \%)$ & $6(20 \%)$ & $6(8 \%)$ & $4(4 \%)$ & $47(18 \%)$ \\
\hline \multicolumn{6}{|l|}{ Women } \\
\hline Sample size & 3 & 5 & 7 & 3 & 18 \\
\hline Number of species proposed & 28 & 38 & 77 & 28 & 171 \\
\hline Unknown species* & $3(11 \%)$ & $6(16 \%)$ & $3(4 \%)$ & $1(4 \%)$ & $13(8 \%)$ \\
\hline Total of species & 89 & 68 & 155 & 126 & 438 \\
\hline Incl. unknown species* & $34(38 \%)$ & $12(18 \%)$ & $9(6 \%)$ & $5(4 \%)$ & $60(14 \%)$ \\
\hline
\end{tabular}

\subsubsection{Vegetation survey}

Vegetation surveys were performed from September to October 2013 in the plain and terraces surrounding the village (over a radius of about $10 \mathrm{~km}$ ), where most agro-pastoral activities take place. Forty-six points were randomly computed with the ArcGIS 10.0 software. Each point was the starting point of a transect guided with a randomly computed azimuth. A vegetation survey was done for each substantial change in vegetation or in abiotic environment (soil, topography). A plot 
consisted in a 50x50 m square where all of the species were recorded and were associated with an abundance-dominance $(A D)$ index (Braun-Blanquet, 1964). A total of 141 plots were performed. For a species $i$, we defined (1) the ecological frequency $(E F)$ as the ratio between the number of plots in which the species $i$ was observed and the total number of plots; and (2) the average $A D$ index as the mean of the $A D$ indexes attributed to the species $i$ in the 141 plots.

\subsection{DATA ANALYSES}

\subsubsection{Free-list analyses}

Free-lists were analyzed with FLAME, an Add-In running on EXCEL® environment, which provides similar analyses to the ANTHROPAC software (Pennec et al., 2012). We calculated $F_{a}$, the frequency of appearance of the ethnospecies $a$ and $S_{a}$, the Smith salience index, which assesses plant cultural value (Smith and Borgatti, 1997), as:

$$
S_{a}=\frac{\sum_{i=1}^{N} \frac{L_{i}-R_{a}+1}{L_{i}}}{N}
$$

with $\quad N$ : Total number of informants;

$L_{i}$ : Size of the list for the informant $i$;

$R_{a}$ : Rank of appearance of the ethnospecies $a$.

The study of the correlation between the Smith salience index and (1) the ecological frequency and (2) the average $A D$ index allowed testing of the ecological apparency hypothesis.

The competence of the informant $i$ in the cultural domain was assessed in a two-dimensional space defined by $L_{i}$ and by the summed frequency $F_{i}=\sum_{a=1}^{L_{i}} F_{a}$. Finally, the distance between two informants $i$ and $j$ was calculated with Jaccard's index of similarity:

$$
\Delta_{i j}=\frac{M_{i 1 j 0}+M_{i 0 j 1}}{M_{i 1 j 0}+M_{i 0 j 1}+M_{i 1 j 1}}
$$

with $\quad M_{i 1 j 0}$ : Number of ethnospecies appearing in the list of $i$ and not in the list of $j$;

$M_{i 0 j 1}$ : Number of ethnospecies appearing in the list of $j$ and not in the list of $i$;

$M_{i 1 j 1}$ : Number of ethnospecies appearing in the lists of $i$ and $j$;

The assessment of informants' competence informed on their plant knowledge on the basis of their capacity to cite plant names during a free-list exercise. 


\subsubsection{Plant use classification and use value}

A principle of triangulation was followed to confirm uses through (1) repetition (cited by at least two persons in two distinct interviews), (2) direct observation or (3) informal confirmation by secondary informants and other villagers. Plants were classified in six categories: medicinal, technological, edible, construction, multi-category and unused (Table 2). We calculated for each plant the reported use value $(R U)$ as the sum of confirmed uses (Gomez-Beloz, 2002). As all ligneous species were found to be useful as firewood, this use was excluded from $R U$ calculation, because it introduced a systematic bias to $R U$ value for woody species. $R U$ thus measures the importance of ethnospecies in terms of number of uses (firewood excluded). It differs from the use value defined by Phillips and Gentry (1993), which measures the number of uses known by each individual for each plant and which would have required extensive interviews (see Discussion). Rather, informants' use knowledge was assessed for each category of use with a use knowledge index $(U K I)$. For instance, the medicinal $U K I$ was defined as the ratio between the number of medicinal uses reported by an informant and the total number of medicinal plants this informant was asked about. As defined, UKI allowed assessment of informant knowledge from their capacity to cite plant uses, as it may differ from their capacity to cite plant names. 
Table 2: Numbers of ethnospecies and reported use value by use category.

\begin{tabular}{|c|c|c|}
\hline Use category & $\begin{array}{c}\text { Number of } \\
\text { ethnospecies }\end{array}$ & $\begin{array}{c}\text { Reported use } \\
\text { value }\end{array}$ \\
\hline Medicine & 40 & 76 \\
\hline - Gastrointestinal & 15 & 22 \\
\hline - Dermatological & 9 & 9 \\
\hline - $\quad$ Respiratory & 4 & 5 \\
\hline - Gynecological/andrological & 2 & 2 \\
\hline - Culture-bound syndromes & 3 & 5 \\
\hline - $\quad$ Pain/febrile diseases & 3 & 3 \\
\hline - Fever & 3 & 3 \\
\hline - $\quad$ Skeleto-muscular & 5 & 7 \\
\hline - Ophthalmological & 1 & 1 \\
\hline - Urological & 3 & 3 \\
\hline - $\quad$ Poisonous animal bites & 1 & 1 \\
\hline - Cardiovascular & 5 & 5 \\
\hline - $\quad$ Other/Unclassified & 9 & 10 \\
\hline Technology and handicraft & 22 & 23 \\
\hline - Goatskin tanning & 5 & 6 \\
\hline - $\quad$ Goatskin cleaning & 5 & 5 \\
\hline - Hair care & 4 & 4 \\
\hline - Oral/ body hygiene & 4 & 4 \\
\hline - Tools and objects & 3 & 3 \\
\hline - $\quad$ Textile cleaning & 1 & 1 \\
\hline Construction & 6 & 6 \\
\hline - $\quad$ Fence & 3 & 3 \\
\hline - Roof & 3 & 3 \\
\hline Edible & 21 & 21 \\
\hline - Snack & 10 & 10 \\
\hline - Herb & 5 & 5 \\
\hline - Food & 4 & 4 \\
\hline - $\quad$ Other & 2 & 2 \\
\hline Total & 68 & 126 \\
\hline Incl. multi-category species & 19 & \\
\hline
\end{tabular}

\subsubsection{Statistics}

Statistics were computed with the R software (R Core Team, 2014). Normal distribution was tested with Shapiro tests. For normal distributions, Student test was used for mean comparisons; for nonnormal distributions, the non-parametric Wilcoxon test was used. As the type of use may affect plant cultural value (Benz et al., 2000), we tested the influence of the use category on the Smith index through the Kruskal-Wallis test and the correlation between Smith index and $R U$ through Spearman test. The EAH was tested through a Spearman test between the plant apparency ( $E F$ and average $A D$ index) and the Smith index. To address the variability of LEK between informants, we analysed the influence of a range of individual socio-economic attributes, including age, gender, main occupation, marital status and nomadic experience (see Appendix A). The influence of age on informant knowledge was tested through a Spearman test and the influence of gender through a Wilcoxon test. An ANOVA was used to test the simultaneous influence of gender and use category on the Smith index. Because of non-normal distributions or heteroscedasticity, the effect of marital 
status and occupation was tested with the Kruskal-Wallis test. Finally, Wilcoxon test was used to address LEK difference between permanently-settled people and former nomads. All tests used a $5 \%$ factor for validation.

\section{Results}

\subsection{RICHNESS OF THE LOCAL ETHNOFLORA}

A total of 164 ethnospecies were mentioned in the free-lists, among which 118 (72\%) were identified to species level and 17 (10\%) to genus level (Appendix B). A total of 43 botanical families and 110 geneses were represented. The most highly represented families included Compositae (20 ethnospecies), Leguminosae (15 ethnospecies) and Amaranthaceae and Brassicaceae (11 ethnospecies each). The average number of ethnospecies listed by informant was 30.0 ( $\pm 9.2 \mathrm{SD})$, with a minimum of 14 for a seventeen year-old man and a maximum of 47 for a forty-three year-old man. Most frequently cited ethnospecies where talh (Acacia tortilis subsp. raddiana; 97\% of the informants), argan (Argania spinosa (L.) Skeels, Sapotaceae; 97\%), șbat (Stipagrostis pungens (Desf.) de Winter, Poaceae; 92\%) and kerkaz (Diplotaxis spp. DC., Brassicaceae; 89\%). Talh had the highest Smith salience index (0.833), followed by argan (0.716), remt (Hammada scoparia; 0.614), mulbeîna (Launea arborescens (Batt.) Murb., Compositae; 0.612 ) and kerkaz (0.596). Only 15 ethnospecies were cited by more than $50 \%$ of the informants and 49 ethnospecies by more than $20 \%$ of them. Additionally, $50 \%$ of the ethnospecies were mentioned by fewer than $9 \%$ of the informants and 45 ethnospecies were mentioned by only one informant.

\subsection{CULTURAL VALUE HETEROGENEITY BETWEEN PLANTS}

\subsubsection{The influence of plant use on plant cultural value}

Useful ethnospecies represented $41 \%$ of the total number of cited ethnospecies and had 126 distinguished uses (Table 2). Useful ethnospecies included 59\% of medicinal, 32\% of technological, $31 \%$ of edible and $9 \%$ of construction plants. Thirty plants $(44 \%)$ had several uses and nineteen (28\%) were multi-category, including 13 medicinal, 10 edible, 12 technological and 5 construction plants. Highest $R U$ were found for talh (10 uses, three categories), remt (6 uses, two categories) and atîl (Maerua crassifolia Forssk., Capparidaceae), chîh (Artemisia sp. L., Compositae) and mheînza (Cleome amblyocarpa Barratte \& Murb., Cleomaceae) (4 uses, two categories). 
Used ethnospecies were more often cited by informants than unused ones: amongst the 49 ethnospecies cited by more than $20 \%$ of the informants, 34 were used and 15 were not. Mean Smith salience index was $0.15( \pm 0.18 \mathrm{SD})$ for used ethnospecies and $0.05( \pm 0.09 \mathrm{SD})$ for unused ones, with a significant difference (Wilcoxon test, $\mathrm{p}<0.001$ ). Additionally, the $R U$ was positively correlated with Smith index (Spearman test, $p<0.001, \rho=0.43$ ) (Figure 2a). Thus the more useful a plant was, the higher was its cultural value.

Use category also influenced salience index (Kruskal-Wallis test, $\mathrm{p}<0.001$ ) (Figure 2b). Mean salience index was highest for species used for construction, with significant differences between every other use category (Wilcoxon test, all $\mathrm{p}<0.01$ ). Conversely, no difference was found between medicinal, edible and technological plants' salience indexes (all p >0.39). Multi-category plants had higher mean salience index than others (respectively, $0.28 \pm 0.26$ and $0.10 \pm 0.10 \mathrm{SD} ; \mathrm{p}=0.010$ ). Unused plants had lower salience index than every other plant category (all $\mathrm{p}<0.001$ ). Thus the type and diversity of uses both influenced the plant cultural value.

a)

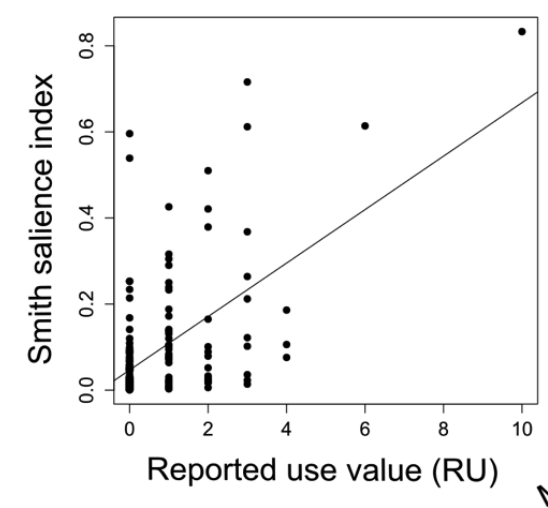

b)

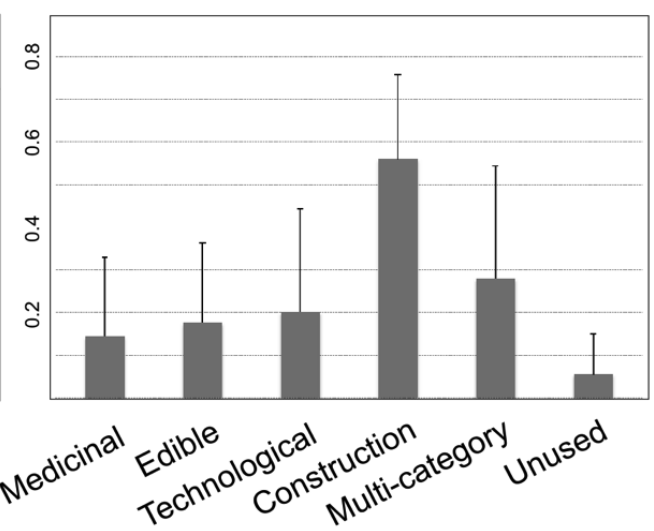

Figure 2: Plant use and salience index. a) Correlation between the reported use value and Smith's salience index; b) Mean Smith salience index by use category (bars represent standard deviation).

\subsubsection{The influence of ecological apparency on plant cultural value}

A total of seventy-one species were observed in the vegetation survey and average species number per plot was of $6.7( \pm 4.6 \mathrm{SD})$. In parallel, only 16 species were found in more than $10 \%$ of the plots. The most frequent species were remt $(E F=94.3 \%)$, mulbeina $(63.8 \%)$ and talh $(56.0 \%)$. Average $A D$ index was the highest for remt $(\mathrm{AD}=1.57)$, mulbeîna $(0.82)$, sedra-l-beị̂̂ and Cynodon dactylon (L.) Pers. (Poaceae) (0.27), kherdeg (0.26) and talh (0.25). The plant ecological frequency was positively correlated with their Smith salience index (Spearman correlation, 
$\mathrm{p}<0.001, \rho=0.47)$. The correlation between the AD index and the Smith index was also positive and significant $(\mathrm{p}<0.001, \rho=0.53)$ but with a fuzzier pattern (Figure 3$)$.

a)

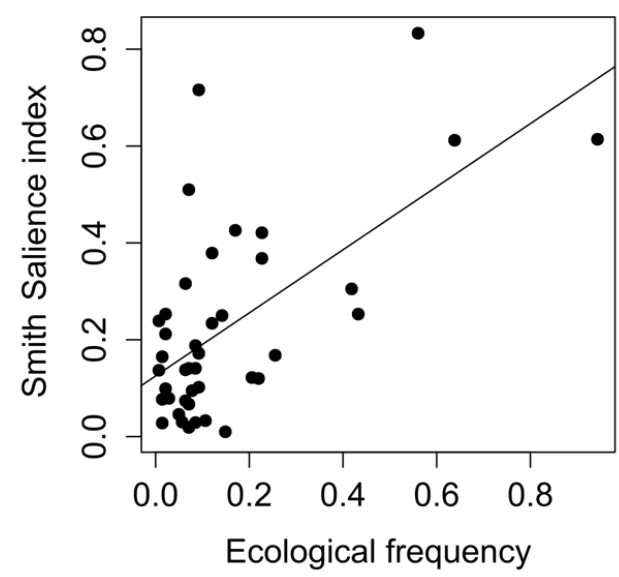

b)

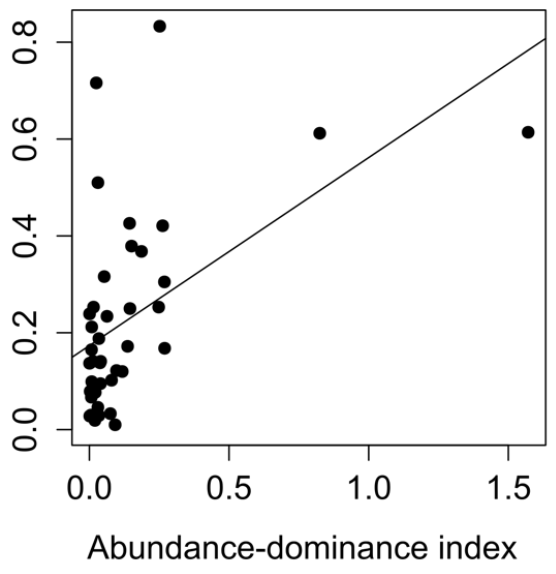

Figure 3: Correlation between ethnospecies Smith salience index and a) the ecological frequency and $b$ ) the abundance-dominance index.

\subsection{LEK DISTRIBUTION BETWEEN INFORMANTS}

\subsubsection{Variability of plant knowledge between informants}

The average number of cited ethnospecies was $30.1( \pm 9.2 \mathrm{SD})$ for men and $29.8( \pm 9.4 \mathrm{SD})$ for women. No correlation was found between age and free-list size (Spearman test, $\mathrm{p}=0.220$ ). Free-list size was not influenced by gender (Wilcoxon test, $\mathrm{p}=1$ ), by marital status (Kruskal-Wallis test, $p=0.324)$ or by informant's main occupation $(p=0.625)$. Furthermore, the informant competence was not patterned by age or gender (Figure 4A). Smith salience index was influenced by the use category (ANOVA, $\mathrm{F}=161.96, \mathrm{p}<0.001)$ but no effect of gender $(\mathrm{F}=0.05, \mathrm{p}=0.822)$ and no interaction between gender and use category was observed $(\mathrm{F}=0.44, \mathrm{p}=0.819)$, as illustrated in Figure 4B. 
a)

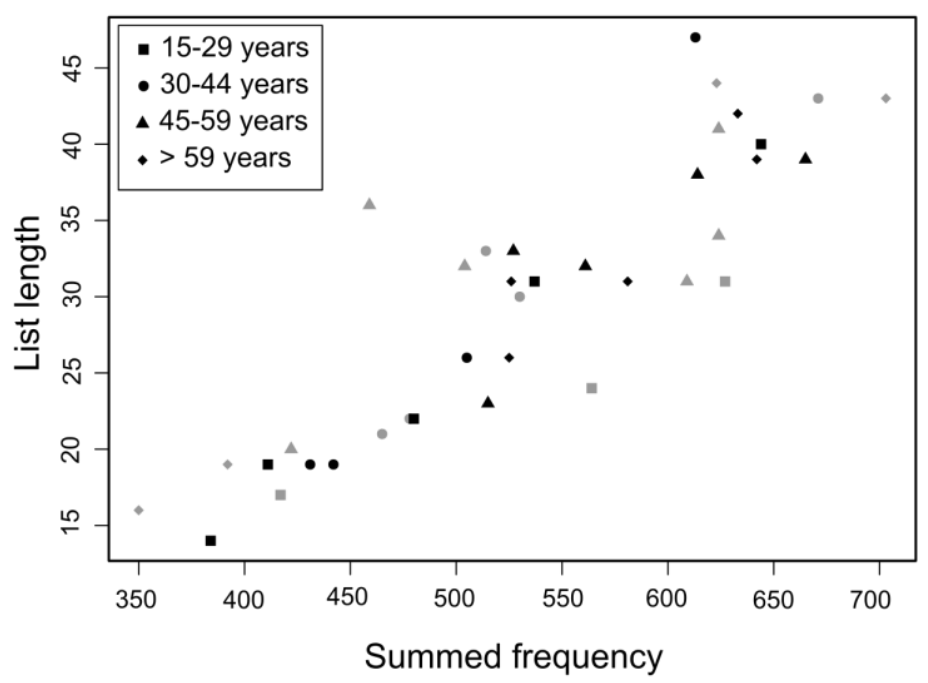

b)

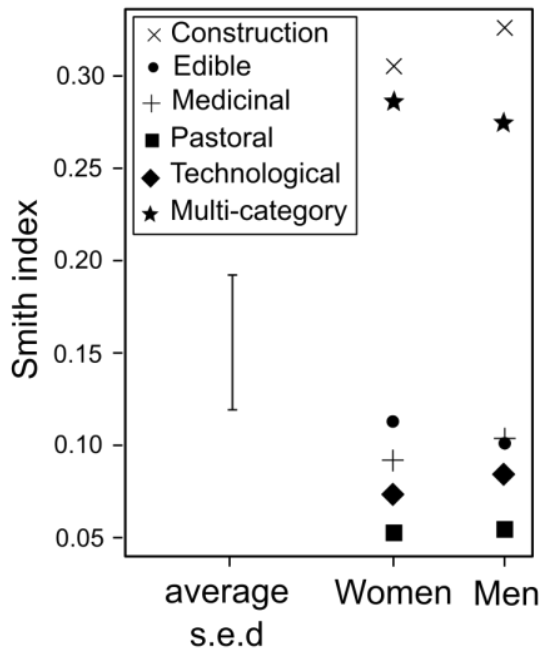

Figure 4: a) Informants' competence according to age and gender (men in black; women in grey). The y coordinate corresponds to the number of ethnospecies he/she mentioned. The $\mathrm{x}$ coordinate corresponds to the sum of frequencies of the ethnospecies he/she mentioned; b) plant Smith salience index variation according to use category and gender obtained from the ANOVA analysis.

In contrast, former nomads named significantly more plants (32.4 $\pm 8.9 \mathrm{SD})$ than permanentlysettled people (24.2 $\pm 7.4 \mathrm{SD}$ ) (Wilcoxon test, $\mathrm{p}=0.01$ ). Smith index differed between former nomads and permanently-settled people $(\mathrm{p}<0.001)$. In parallel, Smith index showed no difference between the 30-44, the 45-59 and the more than 59 year-old informants (Wilcoxon tests, all $\mathrm{p}>0.05)$, while it distinguished the 15-29 year-old informants from all the latter age categories (paired Wilcoxon test, all $\mathrm{p}<0.01)$. Thus, as former nomads $(55.5 \pm 15.0$ SD year-old) were significantly older than permanently-settled people $(30.9 \pm 7.6 \mathrm{SD} ; \mathrm{p}<0.001)$, there may be an autocorrelation between age and nomadic experience. We thus compared Smith index between permanently-settled people only $(\mathrm{N}=12)$ and found no influence of age $(\mathrm{p}=0.09)$. So free-list size and Smith index were more influenced by the nomadic experience than by the age. In addition, the informants' distance matrix showed a core of informants and five groups of outliers (Figure 5). Outliers 1, 2 and 3 included 8 of the 12 permanently-settled informants. This group of outliers was split into men (circle 1) and women (circle 2 and 3). In contrast, informants in circles 4 and 5 (Figure 5) were three middle-aged women who had lived as semi-nomads for more than 20 years before settling. 


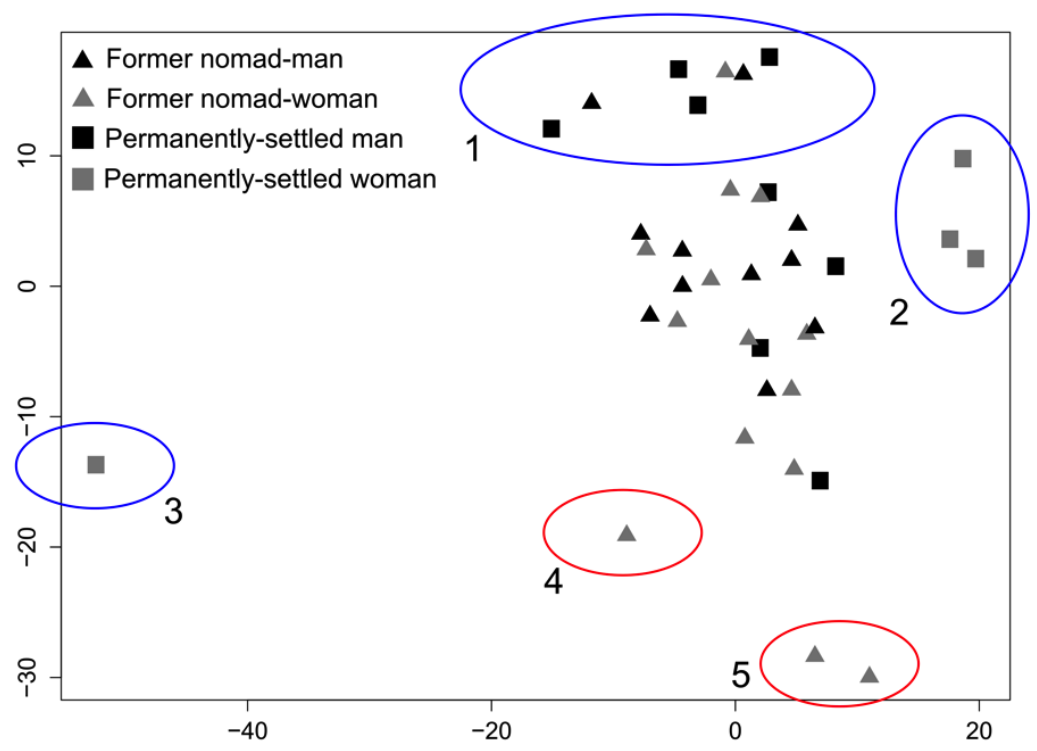

Figure 5: Relative Jaccard's distance between informants. Men are coded in black and women in grey. Squares code for permanently-settled people and triangles for former nomads. Circles indicate groups of outliers.

\subsubsection{Variability in plant use knowledge between informants}

Among the ethnospecies proposed during the semi-structured interviews, the share of unknown species varied with age and gender (Table 1). On average, women knew more species than men, but the difference between genders was very high for the youngest people and tended to disappear with age. The share of unknown species was $6 \%$ for former nomads and $41 \%$ for permanently-settled people while $U K I$ was always lower for the latter (Figure 6). For instance, total $U K I$ was $28.3 \%$ lower for permanently-settled people than for former nomads, but this difference varied between use categories: edible $U K I$ was $42.0 \%$ lower, technological $U K I$ was $42.6 \%$ and medicinal $U K I$ was $22.4 \%$ lower. 


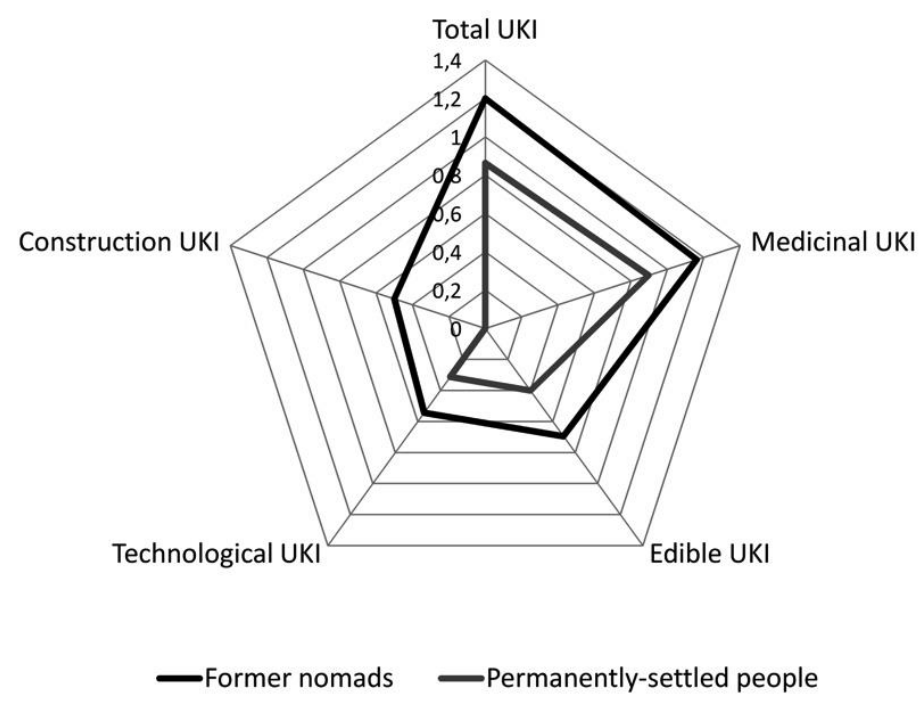

Figure 6: Comparison of Use Knowledge Indexes between former nomads (25 informants) and permanently-settled people (12 informants).

4. Discussion

\subsection{CULTURAL VALUE VARIABILITY AMONG SPECIES}

Our results showed a variation of cultural value between ethnospecies, which is an important and frequent conclusion in ethnobotany studies (e.g. Begossi et al., 2002; Benz et al., 2000; Lawrence et al., 2005; Phillips and Gentry, 1993). Cultural value was furthermore concentrated around a limited number of plants and varied according to their use and apparency.

\subsubsection{Use value vs Cultural value}

Turner (1988) suggested that the cultural value of a plant is "virtually synonymous with use of a plant, when "use" is interpreted in its widest, most general context". Our results indicated a positive correlation between $R U$ and Smith index, which tends to confirm Turner's proposal. For instance, Acacia tortilis subsp. raddiana had the highest $R U$ and Smith index. The latter result was also found by Volpato and Puri (2014) in refugee camps of the Western Sahara, which indicates a high regional valuation of this tree species and its cultural importance. Conversely, Argania spinosa had the second highest Smith index and a relatively low $R U$, which highlights that the use value is not necessarily an optimal proxy of the cultural value. In particular, the plant's pastoral value may also play a substantial role in its cultural valuation (Linstädter et al., 2013). Furthermore, some uses are not material and belong to the immaterial and socio-cultural sphere, through stories, legends, and beliefs. Consequently the Smith salience index may be more reliable to assess the cultural value of 
plants than other use value indexes. On the other hand, the Smith index suffers from several limitations related to the limitations of the free-listing method (see Quinlan and Quinlan, 2007). Quantifying cultural value thus remains a challenging exercise that requires complementary qualitative approaches if it is to be addressed fully and in its full complexity.

\subsubsection{Plant cultural value and use category}

Our results indicate a differential valuation of plants according to the use category. The high valuation of construction may be explained by the fact that it represents only six species and that five of them were multi-category species. Surprisingly, medicinal plants were not more highly valued than edible or technological species, notwithstanding the fact that they represent the greatest richness in terms of species and use. The dominance of medicinal plants is common in the literature, but other uses are also important to fulfil everyday life needs. This is particularly relevant in arid environments where people have developed multi-resource strategies to adapt to risk and uncertainty (Salzman, 2002).

We also noted during the interviews that several informants reported "cognitive use" and not "active use" (sensu de Albuquerque and de Lucena, 2005). For instance, some species were useful for food, cosmetics or hygiene, but only few elders effectively used them, as people now have access to markets for cheap food and other products. We unfortunately were unable to make a systematic distinction between cognitive and active use, mainly because it would have required individual history investigations and long-term observations. This may constitute a limit to establish a nexus between cultural and use values. We therefore recommend for further ethnobotanical studies paying careful attention to distinguishing active use from collective knowledge or from the memory of former practices.

\subsubsection{The ecological apparency hypothesis}

According to the EAH, the largest, most dominant and most frequent plants should have the highest use value (de Lucena et al., 2007). The EAH has been corroborated by several studies, but the correlation then depends on the choice of the indicator used to assess ecological apparency. Authors generally used basal area (e.g. Lawrence et al., 2005; de Lucena et al., 2007), plant frequency and density (Thomas et al., 2009) or number of individuals (Galeano, 2000). If basal area seems appropriate for tree species, we considered that ecological frequency and species cover were better suited to the shrub and grass vegetation of dryland landscapes. Through these indexes, our results showed a higher valuation of more apparent species, which corroborates the EAH. In contrast, the 
absence of correlation with $R U$ may be due to methodological limitations. We used in this study the reported use value defined for a plant as the sum of confirmed uses (Gomez-Beloz, 2002). Other studies that tested the EAH mostly used the overall use value defined as the average use value (UV) obtained from the informants (Phillips and Gentry, 1993a). We think that the $U V$ and the Smith salience index may be more robust for quantitative analyses than $R U$. Our experimental design unfortunately prevented us from calculating $U V$ : because of the high number of ethnospecies, all informants were not interviewed on all the plants. To perform statistically robust tests, we thus worked with group-aggregated $U K I$ rather than with individual indexes.

Furthermore, testing the EAH may not be obvious in drylands and we identified two possible biases in our vegetation survey. On the one hand, the study occurred in a dry year and may underestimate the apparency of species that grow only during wet years (especially annual species). Conversely, a survey that would occur during a wet year may overestimate the apparency of these species. This bias is thus inherent from snapshot studies that fail to address variability. On the other hand, the mobility of nomadic and semi-nomadic people may change their perception of plant apparency. As herders and families move towards diverse rangelands and places seeking for valuable forage (Linstädter et al., 2013), they increase the time during which they are in contact with certain species. They additionally may be in contact with various types of vegetation. As our vegetation survey was done around the village, there may be substantial differences between measured apparency and perceived apparency by former nomads, even if they are now mostly sedentary. Mobility and variability have thus major implications for ethnobotanical studies by implying an enlargement of the duration and of the scale of the study, with particular attention to patterns of movements and to people's life history.

\subsection{SHARING KNOWLEDGE: A SOCIAL RISK-MANAGEMENT STRATEGY?}

\subsubsection{Reciprocal exchange networks of LEK}

Our results indicate no effect of age or gender on plant valuation. In contrast, plants were not evenly used by men and women, as women remain the major prescribers of medicinal plants and construction is men's work. These results contrast with most studies that rather reported an effect of gender specialization and age on plant knowledge (e.g. Luoga et al., 2000; Begossi et al., 2002; Lawrence et al., 2005; Quinlan and Quinlan, 2007) and a limited circulation of knowledge within communities (Ghimire et al., 2004). It cannot be ruled out that the size of our sample (37 free-lists and 53 participants to the interviews) may have failed to reveal variability. However, the size of the village population in itself constituted the main limitation to our sample. Furthermore, increasing 
the sample by undertaking complementary work in another village would have introduced intercultural variation.

Despite this potential limitation, our results are consistent with several studies that addressed intracultural variation in LEK in the African arid regions and reported a relative homogeneous distribution of LEK between gender and age, while most of the heterogeneity was observed between villages (Kristensen and Lykke, 2003; Lykke et al., 2004). Furthermore, these studies and ours focused on people aged over 18, while people may have acquired LEK by adolescence. Consequently, if LEK is homogeneous when adulthood is reached, further study would be necessary to investigate LEK learning during childhood. Considering the influence of plant apparency on plant cultural value, LEK homogeneity between adults may be explained by the fact that people have the same access to plants, even if they do not share knowledge. This assumption would suggest that human culture is primarily shaped by environmental features, but this environmental determinism approach has been challenged by cultural ecology (Geertz, 1963). In particular for LEK, literature suggests that even if plant availability influences LEK, variations between people may still be observed across age (Phillips and Gentry, 1993b) or gender (Lawrence et al., 2005). The alternative hypothesis to explain LEK homogeneity is a broad circulation of knowledge between ages and genders. Several observations made during the fieldwork led us to favour this hypothesis. Firstly, while most medicinal and technological uses were the attribute of women, men described these uses in a detailed manner, which suggested that they possess the know-how. This is consistent with the observations of Volpato and Puri (2014), who observed amongst Sahrawi people in Algeria an occasional involvement of women in men-dedicated work, and suggest that this involvement may contribute to the circulation and homogenization of LEK. Additionally in our study, all informants considered that plant knowledge should be shared with anyone who needs it and affirmed they would share information on plants with any relatives (family and village members, men and women, etc.). Such talk was corroborated by informal discussions and observations of everyday life interactions between people: in case of illness, people received advice and help from their relatives, especially elders, at a broader scale than that of the family. Such social norms may promote the circulation and the homogenization of LEK within Taidalt village. Our result may thus suggest that at village scale, the LEK system is shaped by a reciprocal exchange networks strategy. Further study would nevertheless be required to provide comparison with results at a broader scale. 


\subsubsection{LEK system adaptation to arid environments}

LEK is considered to enable people to sustain a living in their local environment and to be a key point for adaptive co-management - i.e. for the integration of local ecological, social and economic information in management plans by decision makers (Gadgil et al., 2003). In arid environments, which are characterized by a high level of uncertainty and risk, LEK is particularly useful for people's resilience in the face of hazards (Colding et al., 2003). More specifically, it has often been argued that sharing LEK is a key attribute in stochastic environments (Niamir-Fuller, 1999). Our results are consistent with a broad sharing of LEK in drylands, which may be considered as a riskmanagement strategy. Strategies to cope with risk in drylands include mobility, diversity, flexibility, reciprocity and reserves (Fernandez-Gimenez and Le Febre, 2006) and may also be at play for LEK systems. Mobility enables individuals to widen their social and ecological environment and to have access to a diversity of plant and related knowledge. This access is granted by reciprocity, i.e. if individuals agree to share their knowledge among themselves. Reciprocity and mobility thus constitute two requirements for individuals to diversify their knowledge. This diversification and the constitution of an individual set of knowledge in turn increases individuals' flexibility, as more plants and uses are known. Individual flexibility appears as particularly crucial in arid environments, where people often travel alone or in small groups throughout vast and hostile territories for long periods, to browse their animals or seek suitable rangelands. It is not rare that men travel without women, and thus have to be independent enough to cook or treat themselves medically. Constituting an individual pool of knowledge thus enables them to cope with isolation. In adopting a reciprocal exchange networks strategy, people in arid environments contribute to collectively building individual resilience and adaptive capacity (Ruiz-Mallén and Corbera, 2013) in the face of unpredictability, risk and isolation.

Conversely, we also identified in Taidalt village particularly knowledgeable outliers, represented by middle-aged women who were formerly semi-nomads. As different kinds of SRMS often overlap within a society (Moritz et al., 2011), key informants may be the sign of a lesser patron-client relationship strategy. Key informants are considered to be crucial to the maintenance of LEK, while at the same time, their disappearance has detrimental effects on the level of knowledge of the whole village (Begossi et al., 2002). The vulnerability of LEK increases as the size of the group owning this LEK decreases (Agrawal, 1995). Consequently, the homogeneity of LEK within a human group may tend to maximize the number of people owning LEK and to contribute to LEK resilience, while the presence of key informants may be seen as a factor of vulnerability. Complementary, heterogeneous LEK distribution may be a sign of LEK erosion (Benz et al., 2000; Case et al., 2005). The presence of key informants may reflect the negative effects of the sedentary lifestyle on 
LEK as a result of a decrease in mobility and a loss of contact with the learning environment (Ohmagari and Berkes, 1997). Those women, former nomads, may have kept high level of LEK from their nomadic lifestyle, while most of other villagers may have lost theirs. Further study would be required to test this assumption and to better understand the causes and consequences of the presence of key informants. In this perspective, addressing the variability of knowledge between current nomads and settled-people may be especially relevant, whereas a settled lifestyle may not be the only factor of LEK erosion.

\subsection{A THREATENED LEK SYSTEM?}

\subsubsection{Changes in practices and associated LEK erosion}

Our results showed differences in LEK between former nomads and permanently-settled people, which may highlight a LEK change in the face of changing livelihoods. The extent of this change however depends on plant use, because some activities collapse while others continue (Ohmagari and Berkes, 1997). In Taidalt village, all inhabited houses had, at the time of this study, industrial wood roofs, and most new houses are today built with concrete blocks, instead of wattle and daub. Alongside the abandonment of traditional construction practices, permanently-settled informants had very low construction $U K I$. In contrast, the knowledge gap between former nomads and permanently-settled people was the lowest for medicinal plants. Despite there being a health care centre in the village and the proximity of an urban centre, plants still remained an active source of treatment at the time of this study. All informants mixed traditional and allopathic medicine, which is a common phenomenon (Matavele and Habib, 2000). This underpins a process of diversification, rather than of competition, between two complementary medicinal systems that do not exactly cover the same fields of illness. In contrast, modern construction materials may fulfil, or even exceed, all the attributes of traditional ones, which may have favoured substitution processes. Access to a market economy and related goods is known to drastically influence LEK. Most of the time, this influence is negative for LEK conservation, because people tend to replace plant uses and materials with market ones or to change occupations. Sometimes however, markets may positively contribute to LEK, for instance in economically valorizing a plant resource. Thus, the changing economic context may have constrasting effects on LEK and may not impact all LEK in the same way (Benz et al., 2000), as our results suggest. In order to better understand these processes, we suggest that monitoring the variability of LEK between plants and within social groups may be a suitable method to assess LEK system change and potential erosion in a changing context. 


\subsubsection{LEK and agro-pastoral activities: a common future?}

As LEK is rooted in a specific socio-environmental context, it may be threatened by changes of this context. A scientific consensus seems to exist on the close interlocking between LEK, subsistence activities (Galeano, 2000) and people's contact with the learning social and ecological environment (Ohmagari and Berkes, 1997). In Taidalt, young men usually go to school and then look for paid employment. They find temporary jobs in urban areas and may return to the village during periods of unemployment. They consequently spend little time in the learning environment and are poorly implicated in subsistence activities, which may contribute to weakening their LEK. Conversely, young women go to primary and sometimes secondary school, but then settle back in their family before being married. They then contribute to livestock tending and other subsistence activities within the learning environment. This phenomenon may explain the gap of knowledge between young men and young women.

Additionally, traditional semi-nomadic grazing is poorly considered by settlers, because of its harshness and low profitability and because it prevents children from acquiring formal education. The overall conservation of LEK in this region, and in dryland agro-pastoral societies in general, is thus in question. As observed by Hobbs et al. (2014) in the Eastern Sahara, "those who settle lose their desert knowledge, become poor, and find themselves unable to fall back on to the security provided by traditional knowledge and skills". If young generations in dryland societies forget LEK, they will narrow their flexibility as they will not be able to go back to a pastoral lifestyle, and thus will reduce their adaptive capacity (Berkes et al., 2000). On the other hand, Volpato and Puri (2014) observed a phenomenon of LEK dormancy resulting from (1) exclusion from the learning environment, (2) formal education and (3) a shift in cultural values, favoured by the mass media. They nevertheless suggest in a more dynamic perspective that LEK may be revitalized through a return into the learning environment and by means of vertical and horizontal transmission. Homogenous LEK distribution patterns and still living key informants may be beneficial to such renewal, but it would also require the local re-involvement and interest of people in traditional activities. This is challenged in drylands by a regressive environmental discourse blaming pastoralists for desertification (Davis, 2005) and the paucity of integrated policies designed to support or to act together with agro-pastoral activities. At the same time, LEK is considered by scientists as particularly crucial to complete our understanding of drylands and to help to better conserve these vulnerable ecosystems (Reynolds et al., 2007). This worrisome gap between practitioners' and scientists' representations regarding traditional societies, activities and their effects on the environment is not new. But sharing results for some and concern for others may be a 
first step towards more integrated actions towards both nature conservation and also people's welfare and development.

\section{Conclusion}

In the last decades, substantial changes in livelihoods have occurred for human populations in drylands. These changes include sedentarization, the dismissal of traditional subsistence activities and growing contact with the market economy, and have led to structural and functional alterations of the socio-economic sphere. Nevertheless in South-Western Morocco, rural people are still somehow implicated in agro-pastoral activities and have conserved a substantial knowledge of nature. People tend to value plants that are more useful and more easily available, which corresponds to the "opportunistic" behaviour pattern observed for nomad pastoralists (Salzman, 2002). In addition, this study showed a relative intracultural homogeneity of LEK, allowed by the wide circulation of knowledge between people. As LEK systems are embedded in larger social systems (Berkes et al., 2000), this homogeneity may be rooted in the system of social norms based on reciprocity and exchange that characterizes human societies in drylands (Niamir-Fuller, 1999). Furthermore, the homogeneity may ensure the global resilience of LEK systems in the face of context changes by limiting the risk of cultural oscillations. However, the transmission of LEK to the youngest dryland generations may be challenged by a permanently-settled lifestyle and a disconnection with the learning environment. In a context of uncertainty, losing LEK may be highly damaging in narrowing the livelihood options for this population. Revitalizing LEK may consequently be of crucial importance for dryland populations' resilience and their adaptive capacity, which may involve supportive politics in favour of an agro-pastoral mobile lifestyle.

\section{Acknowledgements}

We would like to thank IRD (VIR funding), the Med-Inn-Local program and the ANR (Agence Nationale pour la Recherche, France) for the funding provided for this research ( ${ }^{\circ}$ ANR-12TMED-0001-01), and LMI MediTer and the Cadi Ayyad University of Marrakech for technical and logistical support. We are grateful to Taidalt village inhabitants for their cooperation and especially to Hassan Bouchrouaat for his precious help as a translator and a key facilitator. We finally thank Francis Laloé who substantially contributed to the statistical assessments and analyses of this paper. 


\section{References}

Adger, W.N., 2000. Social and ecological resilience: are they related? Prog. Hum. Geogr. 24, 347-364. doi:10.1191/030913200701540465

Agrawal, A., 1995. Indigenous and scientific knowledge: some critical comments. Dev. Change 26, 413-439.

Andersen, G.L., Krzywinski, K., Talib, M., Saadallah, A.E.M., Hobbs, J.J., Pierce, R.H., 2014. Traditional nomadic tending of trees in the Red Sea Hills. J. Arid Environ. 106, 36-44. doi:10.1016/j.jaridenv.2014.02.009

Begossi, A., Hanazaki, N., Tamashiro, J.Y., 2002. Medicinal plants in the Atlantic forest (Brazil): knowledge, use and conservation. Hum. Ecol. 30, 281-299. doi:10.1023/A:1016564217719

Bellakhdar, J., 1997. La pharmacopee marocaine traditionnelle: Medecine arabe et savoirs populaires. Ibid Press, Paris, $766 \mathrm{p}$.

Benz, B.F., Cevallos E., J., Santana M., F., Rosales A., J., Graf M., S., 2000. Losing knowledge about plant use in the sierra de manantlan biosphere reserve, Mexico. Econ. Bot. 54, 183-191. doi:10.1007/BF02907821

Berkes, F., Colding, J., Folke, C., 2000. Rediscovery of traditional ecological knowledge as adaptive management. Ecol. Appl. 10, 1251-1262. doi:10.1890/1051-0761(2000)010[1251:ROTEKA]2.0.CO;2

Blanco, J., Genin, D., Carrière, S.M., 2015. The influence of Saharan agro-pastoralism on the structure and dynamics of acacia stands. Agric. Ecosyst. Environ. In press. doi:10.1016/j.agee.2015.07.013

Braun-Blanquet, J., 1964. Pflanzensoziologie: grundzüge der vegetationskunde. Springer-Verlag, Wien.

Case, R.J., Pauli, G.F., Soejarto, D.D., 2005. Factors in Maintaining Indigenous Knowledge Among Ethnic Communities of Manus island. Econ. Bot. 59, 356-365. doi:10.1663/0013-0001(2005)059[0356:FIMIKA]2.0.CO;2

Colding, J., Elmqvist, T., Olsson, P., 2003. Living with disturbance: building resilience in social-ecological systems, in: Berkes, F., Colding, J., Folke, C. (Eds.), Navigating Social-Ecological Sustems. Cambridge University Press, NewYork, pp. 163-185.

Coppock, D.L., Ellis, J.E., Swift, D.M., 1986. Livestock Feeding Ecology and Resource Utilization in a Nomadic Pastoral Ecosystem. J. Appl. Ecol. 23, 573-583. doi:10.2307/2404037

Davis, D.K., 2005. Indigenous knowledge and the desertification debate: problematising expert knowledge in North Africa. Geoforum 36, 509-524. doi:10.1016/j.geoforum.2004.08.003

De Albuquerque, U.P., de Lucena, R.F., 2005. Can apparency affect the use of plants by local people in tropical forests? Interciencia 30, 506-511.

De Albuquerque, U.P., Soldati, G.T., Sieber, S.S., Ramos, M.A., de Sa, J.C., de Souza, L.C., 2011. The use of plants in the medical system of the Fulni-ô people (NE Brazil): A perspective on age and gender. J. Ethnopharmacol. 133, 866873. doi:10.1016/j.jep.2010.11.021

De Lucena, R.F.P., de Lima Araújo, E., de Albuquerque, U.P., 2007. Does the Local Availability of Woody Caatinga Plants (Northeastern Brazil) Explain Their Use Value. Econ. Bot. 61, 347-361. doi:10.1663/0013-

0001(2007)61[347:DTLAOW]2.0.CO;2

De Lucena, R.F.P., de Medeiros, P.M., Araújo, E.D.L., Alves, A.G.C., de Albuquerque, U.P., 2012. The ecological apparency hypothesis and the importance of useful plants in rural communities from northeastern Brazil: an assessment based on use value. J. Environ. Manage. 96, 106-15. doi:10.1016/j.jenvman.2011.09.001

Fernandez-Gimenez, M.E., Le Febre, S., 2006. Mobility in pastoral systems: Dynamic flux or downward trend? Int. J. Sustain. Dev. World Ecol. 13, 341-362. doi:10.1080/13504500609469685

Gadgil, M., Olsson, P., Berkes, F., Folke, C., 2003. Exploring the role of local ecological knowledge in ecosystem management: three case studies, in: Berkes, F., Colding, J., Folke, C. (Eds.), Navigating Social-Ecological Systems. Cambridge University Press, New-York, pp. 189-209. 
Galeano, G., 2000. Forest use at the pacific coast of chocó, Colombia: A quantitative approach. Econ. Bot. 54, 358-376. doi:10.1007/BF02864787

Geertz, C., 1963. Agricultural involution. The processes of ecological change in Indonesia. University of California Press, Ltd., London, UK.

Ghimire, S.K., McKey, D., Aumeeruddy-Thomas, Y., 2004. Heterogeneity in Ethnoecological Knowledge and Management of Medicinal Plants in the Himalayas of Nepal: Implications for Conservation. Ecol. Soc. 9, 6. [online] URL: http://www.ecologyandsociety.org/vol9/iss3/art6/

Giday, M., Asfaw, Z., Woldu, Z., Teklehaymanot, T., 2009. Medicinal plant knowledge of the Bench ethnic group of Ethiopia: an ethnobotanical investigation. J. Ethnobiol. Ethnomed. 5, 34. doi:10.1186/1746-4269-5-34

Gomez-Beloz, A., 2002. Plant Use Knowledge of the Winikina Warao: The Case for Questionnaires in Ethnobotany. Econ. Bot. 56, 231-241. doi:10.1663/0013-0001(2002)056[0231:PUKOTW]2.0.CO;2

Hobbs, J.J., Krzywinski, K., Andersen, G.L., Talib, M., Pierce, R.H., Saadallah, A.E.M., 2014. Acacia trees on the cultural landscapes of the Red Sea Hills. Biodivers. Conserv. 23, 2923-2943. doi:10.1007/s10531-014-0755-X

Joumani, A., 2006. Oued Noun - Sud Maroc. Mythes et réalités. Editions L’Harmattan, Paris.

Kristensen, M., Lykke, A.M., 2003. Informant-Based Valuation of Use and Conservation Preferences of Savanna Trees in Burkina Faso. Econ. Bot. 57, 203-217. doi:10.1663/0013-0001(2003)057[0203:IVOUAC]2.0.CO;2

Ladio, a. H., Lozada, M., 2009. Human ecology, ethnobotany and traditional practices in rural populations inhabiting the Monte region: Resilience and ecological knowledge. J. Arid Environ. 73, 222-227.

doi:10.1016/j.jaridenv.2008.02.006

Lawrence, A., Phillips, O.L., Ismodes, A.R., Lopez, M., Rose, S., Wood, D., Farfan, A.J., 2005. Local values for harvested forest plants in Madre de Dios, Peru: Towards a more contextualised interpretation of quantitative ethnobotanical data. Biodivers. Conserv. 14, 45-79. doi:10.1007/s10531-005-4050-8

Linstädter, a., Kemmerling, B., Baumann, G., Kirscht, H., 2013. The importance of being reliable - Local ecological knowledge and management of forage plants in a dryland pastoral system (Morocco). J. Arid Environ. 95, 30-40. doi:10.1016/j.jaridenv.2013.03.008

Luoga, E., Witkowski, E.T.F., Balkwill, K., 2000. Differential utilization and ethnobotany of trees in Kitulanghalo forest reserve and surrounding communal lands, eastern Tanzania. Econ. Bot. 54, 328-343. doi:10.1007/BF02864785

Lykke, a. M., Kristensen, M.K., Ganaba, S., 2004. Valuation of local use and dynamics of 56 woody species in the Sahel. Biodivers. Conserv. 13, 1961-1990. doi:10.1023/B:BIOC.0000035876.39587.1a

Matavele, J., Habib, M., 2000. Ethnobotany in Cabo Delgado, Mozambique: use of medicinal plants. Environ. Dev. Sustain. 2, 227-234. doi:10.1023/A:1011414124429

Moritz, M., Giblin, J., Ciccone, M., Davis, a., Fuhrman, J., Kimiaie, M., Madzsar, S., Olson, K., Senn, M., 2011. Social Risk-Management Strategies in Pastoral Systems: A Qualitative Comparative Analysis. Cross-Cultural Res. 45, 286317. doi:10.1177/1069397111402464

Msanda, F., El Aboudi, A., Peltier, J.P., 2002. Originalité de la flore et de la végétation de l'Anti-Atlas sud-occidental (Maroc). Feddes Repert. 113, 603-615. doi:0.1002/fedr.200290008

Niamir-Fuller, M., 1999. Managing mobility in african rangelands. The legitimization of transhumance. FAO and IT publications, London, UK.

Ohmagari, K., Berkes, F., 1997. Transmission of Indigenous Knowledge and Bush Skills Among the Western James Bay Cree Women of Subarctic Canada. Hum. Ecol. 25, 6-25. doi:10.1023/A:1021922105740

Pennec, F., Wencelius, J., Garine, E., Raimond, C., Bohbot, H., 2012. FLAME.

Phillips, O., Gentry, A.H., 1993a. The useful plants of Tambopata, Peru: I. Statistical hypotheses tests with a new quantitative technique. Econ. Bot. 47, 15-32. doi:10.1007/BF02862203 
Phillips, O., Gentry, A.H., 1993b. The useful plants of Tambopata, Peru: II. Additional hypothesis testing in quantitative ethnobotany. Econ. Bot. 47, 33-43. doi:10.1007/BF02862204

Quinlan, M.B., Quinlan, R.J., 2007. Modernization and medicinal plant knowledge in a Caribbean horticultural village. Med. Anthropol. Q. 21, 169-192. doi:10.1525/MAQ.2007.21.2.169.169

R Core Team, 2014. R: A language and environment for statistical computing. R Found. Stat. Comput. Vienna Austria.

Reynolds, J.F., Smith, D.M.S., Lambin, E.F., Turner, B.L., Mortimore, M., Batterbury, S.P.J., Downing, T.E., Dowlatabadi, H., Fernández, R.J., Herrick, J.E., Huber-Sannwald, E., Jiang, H., Leemans, R., Lynam, T., Maestre, F.T., Ayarza, M., Walker, B., 2007. Global desertification: building a science for dryland development. Science. 316, 84751. doi:10.1126/science.1131634

Ruiz-Mallén, I., Corbera, E., 2013. Community-Based Conservation and Traditional Ecological Knowledge: Implications for Social-Ecological Resilience. Ecol. Soc. 18, 12.

Salzman, P.C., 2002. Pastoral Nomads: Some General Observations Based on Research in Iran. J. Anthropol. Res. 58, 245-264.

Scoones, I., 1994. New directions in pastoral development in Africa, in: Scoones, I. (Ed.), Living with Unvertainty. Intermediate Technology publications, London, UK, pp. 1-36.

Smith, J.J., Borgatti, S.P., 1997. Salience CountsAnd So Does Accuracy: Correcting and Updating a Measure for FreeList-Item Salience. J. Linguist. Anthropol. 7, 208-209. doi:10.1525/jlin.1997.7.2.208

Thomas, E., Vandebroek, I., Sanca, S., Van Damme, P., 2009. Cultural significance of medicinal plant families and species among Quechua farmers in Apillapampa, Bolivia. J. Ethnopharmacol. 122, 60-67. doi:10.1016/j.jep.2008.11.021

Turner, N.J., 1988. "The Importance of a Rose": Evaluating the Cultural Significance of Plants in Thompson and Lillooet Interior Salish. Am. Anthropol. 90, 272-290. doi:10.1525/aa.1988.90.2.02a00020

Volpato, G., Puri, R.K., 2014. Dormancy and Revitalization: The fate of ethnobotanical knowledge of camel forage among Sahrawi nomads and refugees of Western Sahara. Ethnobot. Res. Appl. 12, 183-210. 
Appendix A: Informants' socio-economic data. "Years in tent" column refers to the lifetime spent as semi-nomadic pastoralist.

\begin{tabular}{|c|c|c|c|c|c|c|}
\hline Informant & Gender & Age & Marital statute & Children & Main occupation & $\begin{array}{l}\text { Years in } \\
\text { tent }\end{array}$ \\
\hline ETH1H & Male & 62 & Married & 4 & Worker & 22 \\
\hline ETH2F & Female & 41 & Married & 5 & Housewife & 20 \\
\hline ETH3H & Male & 27 & Single & 0 & Worker & 0 \\
\hline ETH4H & Male & 45 & Married & 3 & Worker & 12 \\
\hline ETH5F & Female & 56 & Single & 0 & Housewife & 30 \\
\hline ETH6F & Female & 21 & Widowed & 1 & Co-op worker & 0 \\
\hline ETH7F & Female & 72 & Married & 3 & Housewife & 32 \\
\hline ETH8H & Male & 25 & Single & 0 & Worker & 0 \\
\hline ЕТН9H & Male & 90 & Married & 3 & Retired & 67 \\
\hline ETH10H & Male & 76 & Married & 8 & Worker & 33 \\
\hline ETH11H & Male & 58 & Married & 2 & Worker & 19 \\
\hline ETH12H & Male & 42 & Married & 0 & Worker & 0 \\
\hline ETH13H & Male & 43 & Married & 3 & Worker & 0 \\
\hline ETH14H & Male & 20 & Single & 0 & Student & 0 \\
\hline ETH15H & Male & 55 & Married & 3 & Worker & 19 \\
\hline ETH16H & Male & 37 & Married & 0 & Shopkeeper & 0 \\
\hline ETH17F & Female & 81 & Married & 3 & Housewife & 62 \\
\hline ETH18H & Male & 43 & Married & 3 & Breeder & 24 \\
\hline ETH19F & Female & 37 & Single & 0 & Co-op worker & 0 \\
\hline ETH20F & Female & 57 & Widowed & 4 & Co-op worker & 40 \\
\hline ETH21H & Male & 57 & Married & 6 & Retired & 19 \\
\hline ETH22F & Female & 44 & Married & 5 & Co-op worker & 15 \\
\hline ETH23F & Female & 47 & Married & $\mathrm{NC}$ & Housewife & 8 \\
\hline ETH24F & Female & 71 & Widowed & 7 & Housewife & 32 \\
\hline ETH25F & Female & 47 & Married & 4 & Co-op worker & 24 \\
\hline ETH26H & Male & 60 & Married & 6 & Worker & 29 \\
\hline ETH27H & Male & 63 & Married & 6 & Businessman & 20 \\
\hline ETH28H & Male & 28 & Single & 0 & Worker & 0 \\
\hline ETH29H & Male & 28 & Single & 0 & Worker & 0 \\
\hline ETH30H & Male & 58 & Married & 5 & Businessman & 20 \\
\hline ETH31F & Female & 58 & Widowed & 3 & Housewife & 21 \\
\hline ETH32F & Female & 41 & Single & 0 & Co-op worker & 18 \\
\hline ETH33F & Female & 48 & Married & 5 & Co-op worker & 22 \\
\hline ETH34F & Female & 33 & Single & 0 & Co-op worker & 16 \\
\hline ETH35F & Female & 25 & Single & 0 & Co-op worker & 0 \\
\hline ETH36F & Female & 58 & Married & 3 & Housewife & 40 \\
\hline ETH37F & Female & 28 & Single & 0 & Shopkeeper & 0 \\
\hline
\end{tabular}


Appendix B: List of the plant species cites by informants, ranked by Smith Salience index score, as associated frequencies and reported use values $(R U)$.

\begin{tabular}{|c|c|c|c|c|c|c|}
\hline Local name & Scientific name & Authority & Botanical family & $\begin{array}{l}\text { Smith } \\
\text { index }\end{array}$ & Freq. & $\boldsymbol{R U}$ \\
\hline talh & $\begin{array}{l}\text { Acacia tortilis subsp. } \\
\text { raddiana }\end{array}$ & (Savi) Brenan & Leguminosae & 0,833 & $97 \%$ & 10 \\
\hline argan & Argania spinosa & (L.) Skeels & Sapotaceae & 0,716 & $97 \%$ & 3 \\
\hline remt & Hammada scoparia & (Pomel) Iljin & Amaranthaceae & 0,614 & $78 \%$ & 6 \\
\hline mulbeîna & Launaea arborescens & (Batt.) Murb. & Compositae & 0,612 & $78 \%$ & 3 \\
\hline kerkaz & Diplotaxis spp. & DC. & Brassicaceae & 0,596 & $89 \%$ & 0 \\
\hline gahwan & Chrysanthemum spp. & & Compositae & 0,539 & $81 \%$ & 0 \\
\hline sder & Ziziphus lotus & (L.) Lam & Rhamnaceae & 0,510 & $81 \%$ & 2 \\
\hline gendîl & Convolvulus trabutianus & Schweinf. \& Muschler & Convolvulaceae & 0,426 & $60 \%$ & 1 \\
\hline kherdeg & Lycium intricatum & Boiss. & Solanaceae & 0,421 & $62 \%$ & 2 \\
\hline șbat & Stipagrostis pungens & (Desf.) de Winter & Poaceae & 0,379 & $92 \%$ & 2 \\
\hline mrekba & Panicum turgidum & Forssk. & Poaceae & 0,368 & $70 \%$ & 3 \\
\hline rtem & Retama raetam & (Forssk.) Webb & Leguminosae & 0,316 & $60 \%$ & 1 \\
\hline ședra-l-beîda & Farsetia aegyptia & Turra & Brassicaceae & 0,305 & $46 \%$ & 1 \\
\hline garșa & Limonium sinuatum & $\begin{array}{l}\text { (L.) Mill. } \\
\text { Benthem ex Benth. \& }\end{array}$ & Plumbaginaceae & 0,290 & $57 \%$ & 1 \\
\hline afasas & Warionia saharae & Coss. & Compositae & 0,264 & $54 \%$ & 3 \\
\hline hebalya & Heliotropium bacciferum & Forssk. & Boraginaceae & 0,253 & $46 \%$ & 0 \\
\hline hara & Eruca vesicaria & (L.) Cav. & Brassicaceae & 0,253 & $65 \%$ & 0 \\
\hline jefna & Gymnocarpos decander & Forssk. & Caryophyllaceae & 0,250 & $43 \%$ & 1 \\
\hline daghmûs & $\begin{array}{l}\text { Euphorbia officinarum } \\
\text { subsp. echinus } \\
\text { Podospermum laciniatum }\end{array}$ & $\begin{array}{l}\text { (Hook.f. \& Coss.) Vindt } \\
\text { (Guss.) Gemeinholzer \& }\end{array}$ & Euphorbiaceae & 0,239 & $38 \%$ & 1 \\
\hline gharîma & subsp. decumbens & Greuter & Compositae & 0,234 & $46 \%$ & 0 \\
\hline tafsa & Astericus graveolens & (Forssk.) Less. & Compositae & 0,233 & $35 \%$ & 1 \\
\hline gerțîfa & Brocchia cinerea & (Delile) Vis. & Compositae & 0,214 & $41 \%$ & 0 \\
\hline k'aîlt-l-khê̂l & Lavandula coronopifolia & Poir. & Lamiaceae & 0,212 & $43 \%$ & 3 \\
\hline khubuîza & Malva parviflora & L. & Malvaceae & 0,188 & $38 \%$ & 1 \\
\hline chîh & Artemisia sp. & L. & Compositae & 0,186 & $38 \%$ & 4 \\
\hline tasra & Salsola vermiculata & L. & Amaranthaceae & 0,172 & $35 \%$ & 1 \\
\hline njem & Cynodon dactylon & (L.) Pers. & Poaceae & 0,168 & $46 \%$ & 0 \\
\hline halab & Periploca laevigata & Aiton & Apocynaceae & 0,165 & $30 \%$ & 2 \\
\hline tazya & Asphodelus tenuifolius & Cav. & Xanthorrhoeaceae & 0,141 & $30 \%$ & 1 \\
\hline henzab & Emex spinosa & (L.) Campd. & Polygonaceae & 0,141 & $32 \%$ & 0 \\
\hline rikum & Traganopsis glomerata & Maire \& Wilczek & Amaranthaceae & 0,138 & $22 \%$ & 1 \\
\hline demban & Caylusea hexagona & (Forssk.) M.L. Green & Resedaceae & 0,137 & $35 \%$ & 1 \\
\hline hemuîda & Rumex vesicarius & L. & Polygonaceae & 0,131 & $35 \%$ & 1 \\
\hline hedej & Citrullus colocynthis & (L.) Schrad. & Cucurbitaceae & 0,122 & $30 \%$ & 3 \\
\hline deza & Aizoon canariense & L. & Aizoaceae & 0,120 & $22 \%$ & 0 \\
\hline chdîda & Ephedra alata & Decne. & Ephedraceae & 0,120 & $22 \%$ & 1 \\
\hline tabazwagt & Morettia canescens & Boiss. & Brassicaceae & 0,109 & $22 \%$ & 0 \\
\hline atîl & Maerua crassifolia & Forssk. & Capparidaceae & 0,106 & $22 \%$ & 4 \\
\hline
\end{tabular}




\begin{tabular}{|c|c|c|c|c|c|c|}
\hline bûllṣeîg & Forsskaolea tenacissima & $\mathrm{L}$. & Urticaceae & 0,105 & $30 \%$ & 1 \\
\hline gerd & Trigonella anguina & Delile & Leguminosae & 0,104 & $27 \%$ & 1 \\
\hline chendgûra & Ajuga iva & (L.) Schreb. & Lamiaceae & 0,102 & $19 \%$ & 1 \\
\hline kemcha & Anastatica hierochuntica & $\mathrm{L}$. & Brassicaceae & 0,102 & $22 \%$ & 3 \\
\hline jụarî & Searsia tripartita & (Ucria) Moffett & Anacardiaceae & 0,101 & $22 \%$ & 2 \\
\hline behma & Stipa capensis & Thunb. & Poaceae & 0,099 & $30 \%$ & 0 \\
\hline rmeîmida & Euphorbia calyptrata & Coss. \& Kralik & Euphorbiaceae & 0,095 & $16 \%$ & 1 \\
\hline șekûm & Asparagus sp. & & Asparagaceae & 0,095 & $14 \%$ & 0 \\
\hline ntel & Medicago sp. & & Leguminosae & 0,091 & $24 \%$ & 0 \\
\hline chgara & Matthiola maroccana & Coss. & Brassicaceae & 0,091 & $16 \%$ & 0 \\
\hline kamûn-ṣofî & Ammodaucus leucotrichus & Coss. & Apiaceae & 0,089 & $24 \%$ & 2 \\
\hline țarfa & Tamarix sp. & & Tamaracicaceae & 0,087 & $22 \%$ & 0 \\
\hline bûkerkar & Calendula maroccana & (Ball.) Ball & Compositae & 0,085 & $19 \%$ & 0 \\
\hline achakan & Glossonema boveanum & (Decne.) Decne & Apocynaceae & 0,084 & $24 \%$ & 1 \\
\hline ghjeîblî & $\begin{array}{l}\text { Caralluma retrospiciens } \\
\text { Anvillea garcinii subsp. }\end{array}$ & $\begin{array}{l}\text { (Ehrenb.) N.E.Br. } \\
\text { (Coss. \& Durieu) }\end{array}$ & Apocynaceae & 0,080 & $19 \%$ & 1 \\
\hline negd & radiata & Anderb. & Compositae & 0,079 & $22 \%$ & 2 \\
\hline harcha & Echium horridum & Batt. & Boraginaceae & 0,078 & $16 \%$ & 0 \\
\hline skirbeda & & & & 0,077 & $14 \%$ & 1 \\
\hline mheînza & Cleome amblyocarpa & Barratte \& Murb. & Cleomaceae & 0,076 & $19 \%$ & 4 \\
\hline chbarțû & Kleinia anteuphorbium & (L.) Haw. & Compositae & 0,075 & $14 \%$ & 1 \\
\hline azatîm & Limonium sinuatum & (L.) Mill. & Plumbaginaceae & 0,074 & $16 \%$ & 0 \\
\hline ghalga & Pergularia tomentosa & $\mathrm{L}$. & Asclepiadaceae & 0,074 & $16 \%$ & 1 \\
\hline tûrja & Calotropis procera & (Aiton) Dryand. & Apocynaceae & 0,072 & $19 \%$ & 1 \\
\hline d'aîfa & Paronychia argentea & Lam. & Caryophyllaceae & 0,071 & $14 \%$ & 0 \\
\hline mhạâus & Lotus jolyi & $\begin{array}{l}\text { Batt. } \\
\text { (Girard) M B Crespo \& }\end{array}$ & Leguminosae & 0,067 & $14 \%$ & 0 \\
\hline $\begin{array}{l}\text { imsleg } \\
\text { wuden-l- }\end{array}$ & Ceratolimon feei & Lledò & Plumbaginaceae & 0,064 & $16 \%$ & 0 \\
\hline n'âja & Picris asplenioides & $\mathrm{L}$. & Compositae & 0,059 & $14 \%$ & 1 \\
\hline mgheîzlî & Volutaria crupinoides & (Desf.) Cass. ex Maire & Leguminosae & 0,059 & $11 \%$ & 0 \\
\hline ‘âṣal & Salsola longifolia & Forssk. & Amaranthaceae & 0,055 & $11 \%$ & 0 \\
\hline qch'ân & & & & 0,054 & $8 \%$ & 0 \\
\hline azûkenî & Thymus spp. & $\mathrm{L}$. & Lamiaceae & 0,052 & $19 \%$ & 0 \\
\hline hmar-ras & Calendula spp. & $\mathrm{L}$. & Leguminosae & 0,051 & $11 \%$ & 2 \\
\hline tagerma & Carrichtera аппиа & (L.) DC. & Brassicaceae & 0,050 & $8 \%$ & 0 \\
\hline yelma & Plantago spp. & & Plantaginaceae & 0,049 & $8 \%$ & 0 \\
\hline chga' $\hat{a}$ & Matthiola maroccana & Coss. & Brassicaceae & 0,049 & $14 \%$ & 0 \\
\hline tlîha & Fagonia cretica & $\mathrm{L}$. & Zygophyllaceae & 0,049 & $11 \%$ & 0 \\
\hline maker & Launaea mucronata & (Forssk.) Muschl. & Asteraceae & 0,048 & $8 \%$ & 0 \\
\hline belbal & Sarcocornia fruticosa & (L.) A.J. Scott & Amaranthaceae & 0,046 & $8 \%$ & 0 \\
\hline 'âdres & Commiphora africana & (A.Rich.) Endl. & Burseraceae & 0,044 & $11 \%$ & 0 \\
\hline gețaf & Atriplex halimus & $\mathrm{L}$. & Amaranthaceae & 0,036 & $8 \%$ & 0 \\
\hline yergîg & Helianthemum lippii & (L.) Dum. Cours & Cistaceae & 0,036 & $11 \%$ & 3 \\
\hline tazûkenît & Salvia aegyptiaca & $\mathrm{L}$. & Lamiaceae & 0,033 & $11 \%$ & 0 \\
\hline s'âdan & Neurada procumbens & $\mathrm{L}$. & Neuradaceae & 0,031 & $14 \%$ & 2 \\
\hline$z r e \hat{i g a}$ & Eryngium illicifolium & Lam. & Apiaceae & 0,030 & $5 \%$ & 0 \\
\hline demya & Ogastemma pusillum & (Coss. \& Durieu ex & Boraginaceae & 0,030 & $8 \%$ & 1 \\
\hline
\end{tabular}




\begin{tabular}{|c|c|c|c|c|c|c|}
\hline & & $\begin{array}{l}\text { Bonnet \& Barratta) } \\
\text { Brummitt }\end{array}$ & & & & \\
\hline mhêirsa & Astragalus sp. & & Leguminosae & 0,030 & $11 \%$ & 0 \\
\hline bûngîr & Centaurea pungens & Pomel & Compositae & 0,029 & $11 \%$ & 0 \\
\hline mdîsma & Fagonia sp. & & Zygophyllaceae & 0,028 & $11 \%$ & 2 \\
\hline tadût & Acacia gummifera & Willd. & Leguminosae & 0,028 & $8 \%$ & 0 \\
\hline tûfl'âlef & & & & 0,026 & $5 \%$ & 0 \\
\hline luwaya & Convolvulus althaeö̈des & $\mathrm{L}$. & Convolvulaceae & 0,026 & $8 \%$ & 0 \\
\hline berwag & Asphodelus microcarpus & Salzm. \& Viv. & Xanthorrhoeaceae & 0,026 & $5 \%$ & 0 \\
\hline tamat & Acacia ehrenbergiana & Hayne & Leguminosae & 0,024 & $5 \%$ & 0 \\
\hline defla & Nerium oleander & L. & Apocynaceae & 0,023 & $8 \%$ & 2 \\
\hline suwed & Suaeda vermiculata & Forssk. Ex J.F.Gmel. & Amaranthaceae & 0,023 & $3 \%$ & 0 \\
\hline terfas & Terfezia ovalispora & Pat. & Terfeziaceae & 0,023 & $3 \%$ & 0 \\
\hline ‘âgaya & Tetraena gaetula & $\begin{array}{l}\text { (Emb. \& Maire) Beier \& } \\
\text { Thulin }\end{array}$ & Zygophyllaceae & 0,023 & $5 \%$ & 2 \\
\hline talkụ̣̂a & Chenopodium murale & L. & Amaranthaceae & 0,023 & $11 \%$ & 3 \\
\hline tê̂chat & Balanites aegyptiaca & (L.) Delile & Zygophyllaceae & 0,022 & $8 \%$ & 1 \\
\hline jîl & Salsola foetida & Delile & Amaranthaceae & 0,022 & $3 \%$ & 0 \\
\hline igîz. & & & & 0,021 & $3 \%$ & 0 \\
\hline $\begin{array}{l}\text { gharîma-l- } \\
\text { ghzal }\end{array}$ & Launaea capitata & (Spreng.) Dandy & Compositae & 0,021 & $5 \%$ & 0 \\
\hline gzâh & Deverra scoparia & Coss. \& Durrieu & Apiaceae & 0,021 & $5 \%$ & 1 \\
\hline fersîg & Tamarix sp. & & Tamaracicaceae & 0,021 & $3 \%$ & 0 \\
\hline yazîr & Rosmarinus officinalis & $\mathrm{L}$. & Lamiaceae & 0,021 & $5 \%$ & 0 \\
\hline klîkha & & & & 0,020 & $3 \%$ & 1 \\
\hline fûla & Crotalaria saharae & Coss. & Leguminosae & 0,020 & $5 \%$ & 0 \\
\hline besbas & Foeniculum vulgare & Mill. & Apiaceae & 0,020 & $3 \%$ & 0 \\
\hline marar & Volutaria lippii & (L.) Cass. Ex maire & Compositae & 0,020 & $5 \%$ & 1 \\
\hline $\begin{array}{l}\text { rli bouch } \\
\text { gharîma-l- }\end{array}$ & & & & 0,019 & $3 \%$ & 0 \\
\hline hmar & Launaea nudicaulis & (L.) Hook.f. & Compositae & 0,019 & $5 \%$ & 0 \\
\hline z’âîd & Cyperus sp. & & Cyperaceae & 0,019 & $5 \%$ & 0 \\
\hline tamîa & & & & 0,019 & $5 \%$ & 0 \\
\hline nsîl & Stipagrostis plumosa & Munro ex T.Anderson & Poaceae & 0,019 & $11 \%$ & 0 \\
\hline $\begin{array}{l}\text { menûar-l- } \\
\text { ghzal }\end{array}$ & & & & 0,018 & $3 \%$ & 0 \\
\hline awskûn & & & & 0,018 & $5 \%$ & 0 \\
\hline harmel & Peganum harmala & L. & Zygophyllaceae & 0,018 & $5 \%$ & 0 \\
\hline $\begin{array}{l}\text { awriwur } \\
\text { mesran-l- }\end{array}$ & Ricinus communis & $\mathrm{L}$. & Euphorbiaceae & 0,018 & $5 \%$ & 2 \\
\hline hwar & Beta patteralis & Moq. & Amaranthaceae & 0,017 & $5 \%$ & 2 \\
\hline gîz. & Scorzonera undulata & Vahl & Compositae & 0,017 & $3 \%$ & 0 \\
\hline aṭ̂g & Lotus glinoides & Delile & Leguminosae & 0,017 & $5 \%$ & 1 \\
\hline ṣlîha & & & & 0,017 & $3 \%$ & 0 \\
\hline hema & Eremobium aegyptiacum & $\begin{array}{l}\text { (Spreng.) Asch. Ex } \\
\text { Boiss. }\end{array}$ & Brassicaceae & 0,016 & $8 \%$ & 0 \\
\hline talhat-d-ḍob & & & & 0,014 & $3 \%$ & 0 \\
\hline kharibach & & & & 0,014 & $3 \%$ & 0 \\
\hline rebrûba & Brocchia cinerea & (Delile) Vis. & Compositae & 0,014 & $3 \%$ & 0 \\
\hline khzama & Lavandula angustifolia & (DC.) Guinea & Lamiaceae & 0,014 & $3 \%$ & 0 \\
\hline
\end{tabular}


subsp. pyrenaica

\begin{tabular}{|c|c|c|c|c|c|}
\hline $\begin{array}{l}\text { mulkfifat } \\
\text { (bûsrisra) }\end{array}$ & Lupinus digitatus & Forssk. & Leguminosae & 0,013 & $5 \%$ \\
\hline timzira & & & & 0,012 & $3 \%$ \\
\hline aserkena & Adenocarpus cincinnatus & (Ball) Maire & Leguminosae & 0,012 & $3 \%$ \\
\hline igrîz & & & & 0,012 & $3 \%$ \\
\hline eymîm & Reseda sp. & L. & Resedaceae & 0,011 & $5 \%$ \\
\hline kerkaz-l- & & & & & \\
\hline 'âchar & Diplotaxis spp. & DC. & Brassicaceae & 0,011 & $3 \%$ \\
\hline kbîbet-d-ḍob & Euphorbia granulata & Forssk. & Euphorbiaceae & 0,010 & $3 \%$ \\
\hline tîlûm & & & & 0,009 & $3 \%$ \\
\hline $\begin{array}{l}\text { sgî'ât-l- } \\
\text { erneb } \\
\text { wuden-l- }\end{array}$ & Androcymbium gramineum & (Cav.) J.F.Macbr. & Colchicaceae & 0,008 & $3 \%$ \\
\hline halûf & & & & 0,008 & $3 \%$ \\
\hline ghasûl & Aizoon spp. & & Aizoaceae & 0,008 & $5 \%$ \\
\hline kîker & Vicia sativa & L. & Leguminosae & 0,008 & $8 \%$ \\
\hline zrî'ât-l-ktan & Linum usitatissimum & L. & Linaceae & 0,007 & $3 \%$ \\
\hline sbût-l-far & Polypogon maritimus & Willd. & Poaceae & 0,007 & $5 \%$ \\
\hline jamra & Gymnocarpos sclerocephalus & $\begin{array}{l}\text { (Decne.) Dahlgren \& } \\
\text { Thulin }\end{array}$ & Caryophyllaceae & 0,007 & $3 \%$ \\
\hline â̂rmîd & Haplophyllum sp. & A. Jussieu & Rutaceae & 0,007 & $3 \%$ \\
\hline tîzkha & & & & 0,007 & $3 \%$ \\
\hline kharw'â & & & & 0,007 & $3 \%$ \\
\hline gî̀d-n'âm & Kickxia aegyptiaca & (L.) Nàbelek & Plantaginaceae & 0,007 & $3 \%$ \\
\hline chîhaya & Artemisia reptans & C.Sm. Ex Link & Compositae & 0,006 & $3 \%$ \\
\hline beșlat-d-dib & Albuca amoena & $\begin{array}{l}\text { (Batt.) J.C.Manning \& } \\
\text { Goldblatt }\end{array}$ & Asparagaceae & 0,006 & $5 \%$ \\
\hline fernan & Euphorbia regis-jubae & J.Gay & Euphorbiaceae & 0,005 & $5 \%$ \\
\hline fsîet-l-chîkh & Plocama reboudiana & $\begin{array}{l}\text { (Coss. \& Durieu) } \\
\text { M.Backlund \& Thulin }\end{array}$ & Rubiaceae & 0,005 & $3 \%$ \\
\hline tenas & Trichodesma calcaratum & Coss. \& Batt. & Boraginaceae & 0,005 & $3 \%$ \\
\hline khnînîza & & & & 0,005 & $3 \%$ \\
\hline ibsîss-n'âj & & & & 0,005 & $3 \%$ \\
\hline$s b^{\prime} \hat{a}-l-{ }^{\prime} a b t$ & Ifloga spicata & (Forssk.) Sch.Bip. & Compositae & 0,005 & $3 \%$ \\
\hline 'âneb-d-dib & Solanum nigrum & Mill. & Solanaceae & 0,004 & $3 \%$ \\
\hline tîmkîlt & & & & 0,004 & $3 \%$ \\
\hline akhir dib & & & & 0,004 & $3 \%$ \\
\hline smar & Juncus maritimus & Lam. & Juncaceae & 0,003 & $3 \%$ \\
\hline kerkaz-l- & Dinlotaxis snn & $\mathrm{DC}$ & & & $50 \%$ \\
\hline knaiba & Dipioiaxts spp. & DC. & Brassicaceae & 0,003 & $5 \%$ \\
\hline greizni & & & & 0,003 & $3 \%$ \\
\hline askaf & Nucularia perrinii & Batt. & Amaranthaceae & 0,003 & $3 \%$ \\
\hline tîfaf & Sonchus spp. & & Compositae & 0,001 & $3 \%$ \\
\hline bûchwîka & & & & 0,001 & $3 \%$ \\
\hline raret-l-erneb & & & & 0,001 & $3 \%$ \\
\hline seliane & & & & 0,001 & $3 \%$ \\
\hline
\end{tabular}

